\title{
Teacher perceptions of the effectiveness of the Social Studies Teacher Training Program at Tabouk Teachers' College in Saudi Arabia
}

Awad Hamad Alhwiti

West Virginia University

Follow this and additional works at: https://researchrepository.wvu.edu/etd

\section{Recommended Citation}

Alhwiti, Awad Hamad, "Teacher perceptions of the effectiveness of the Social Studies Teacher Training Program at Tabouk Teachers' College in Saudi Arabia" (2007). Graduate Theses, Dissertations, and Problem Reports. 2775.

https://researchrepository.wvu.edu/etd/2775

This Dissertation is protected by copyright and/or related rights. It has been brought to you by the The Research Repository @ WVU with permission from the rights-holder(s). You are free to use this Dissertation in any way that is permitted by the copyright and related rights legislation that applies to your use. For other uses you must obtain permission from the rights-holder(s) directly, unless additional rights are indicated by a Creative Commons license in the record and/ or on the work itself. This Dissertation has been accepted for inclusion in WVU Graduate Theses, Dissertations, and Problem Reports collection by an authorized administrator of The Research Repository @ WVU.

For more information, please contact researchrepository@mail.wvu.edu. 
Teacher Perceptions of the Effectiveness of the Social Studies Teacher Training Program at Tabouk Teachers' College in Saudi Arabia

by

Awad Hamad Alhwiti

Dissertation submitted to the College of Human Resources and Education at West Virginia University

in partial fulfillment of the requirements

for the degree of

Doctor of Education

in

Curriculum and Instruction

Approved by

Perry D. Phillips, Ed.D., Chair

Ernest R. Goeres, Ph.D.

C. Kenneth Murray, Ph.D.

Steve Rinehart, Ed.D.

Phil Ice, Ed.D.

Department of Curriculum \& Instruction/Literacy Studies

Morgantown, West Virginia

2007

Keywords: Teacher Effectiveness, Social Studies Training, Teacher Training Program 


\begin{abstract}
Teacher Perceptions of the Effectiveness of the Social Studies Teacher Training Program at Tabouk Teachers' College in Saudi Arabia
\end{abstract}

By Awad Hamad Alhwiti

The purpose of the study was to examine and evaluate the effectiveness of the social studies teacher training program in Tabouk Teachers' College in Saudi Arabia. This research addressed six questions concerning teacher perceptions regarding the effectiveness of the teacher preparation programs in Tabouk Teachers' College. These questions examined teacher perceptions of the effectiveness of preparation they received for teaching in schools in Saudi Arabia. This study included teachers who completed student teaching and who graduated with a major in social studies. The 40-item instrument used to gather data included demographics, internship, instructor effectiveness, curriculum, teaching skills, classroom management, and three open ended questions. Teachers perceived that the program prepared them to teach within the principles of Islam, and for teaching in Saudi Arabia schools. They also perceived that the program met the needs of Saudi society. Results show that the teachers gave high ratings for their preparation in using a variety of teaching skills and learning proactive classroom management techniques. Teachers expressed a need for more exposure to non-traditional teaching techniques and more emphasis on the use of technology in instruction. They also advocated for an improved connection between the social studies courses and the elementary curriculum. A major implication was that the program supports teachers to teach within Islamic principles, and it serves a vehicle for networking with graduates. Teachers expressed the need to be involved in developing the social studies curriculum of Tabouk Teachers' College and in establishing a link with the elementary social studies curriculum as taught in the elementary schools. 


\section{DEDICATION}

To my Dear father, Hamad Alfutahi and to my mother Khadra;

to my brothers and sisters;

to my wife and my children: Hassan, Suha, Duha, Lama,and Basmah;

to Prince Fahd bin Sultan bin Abdulaziz, Governor of Tabouk Region. Since high school he has encouraged me to study for the doctoral degree. 


\section{ACKNOWLEDGEMENTS}

The writer wishes to take this opportunity to thank Allah for the completion of this dissertation. I am extremely grateful to my parents for their love, support, and prayers. From a pure and humble heart this writer would like to express his deepest thanks to the following people who have helped to make this work possible. First of all, I would like to extend my sincere appreciation and thanks to my dissertation chairman, Dr. Perry Phillips, for his continuous advice, guidance, and personal care. He provided valuable time, expertise, professionalism, and true friendship. His help and support cannot be measured. He gave so many hours far beyond the responsibilities of a committee chairman. My gratitude is also extended to all the members of my committee: Dr. Ernest R. Goeres, Dr. C. Kenneth Murray, Dr. Steve Rinehart, and Dr. Phil Ice.

A very special acknowledgment goes to my dear father, Hamad Alfutahi, for his constant prayers, love and patience. Also, special acknowledgment and most importantly, I appreciate the love and encouragement from my mother, Khadra Alfutahi. Special appreciation is reserved for all my family members, particularly my brothers, Mohammad, Ahmed, Hamdan, and Audah, and my sisters, Hamedah, Hamdah, Salma, Norah, and Newer, and my wife, Gadah, and my children, Hassan, Suha, Duha, Lama, and Basmah. 
Table of Contents

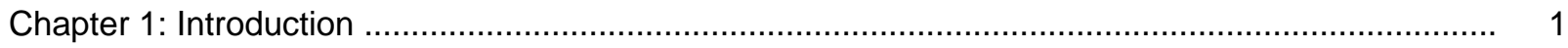

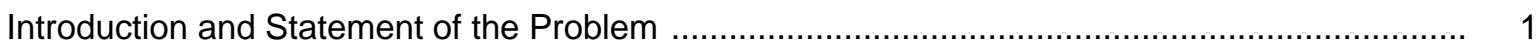

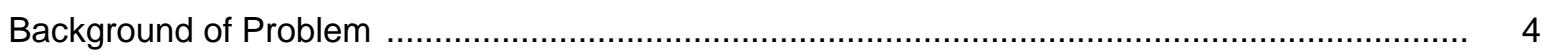

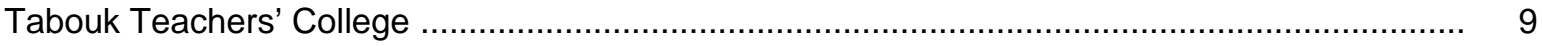

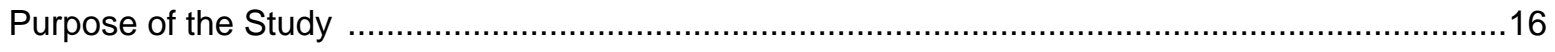

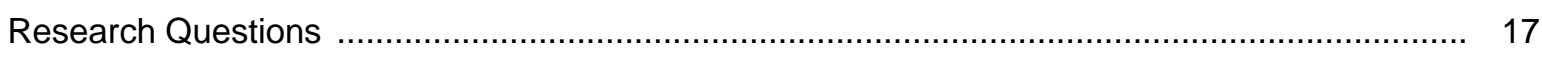

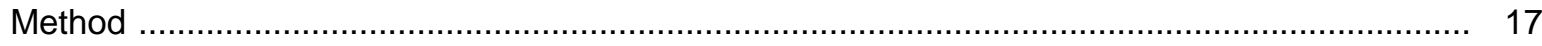

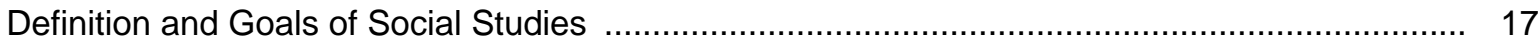

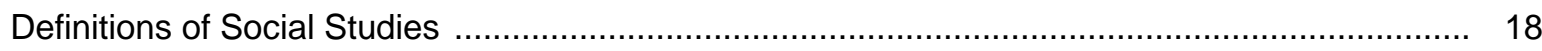

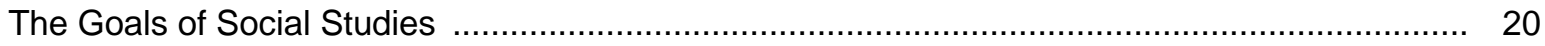

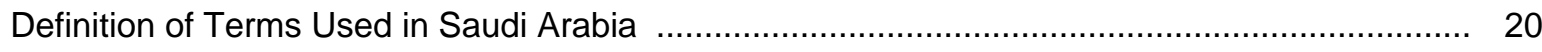

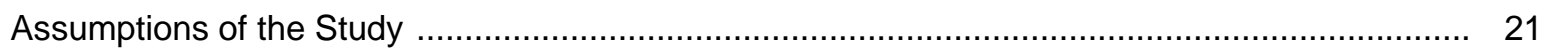

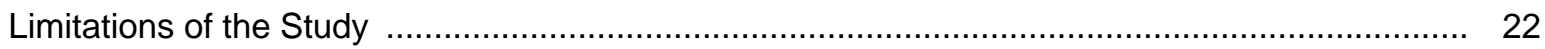

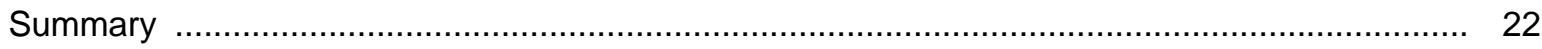

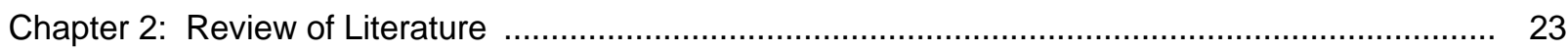

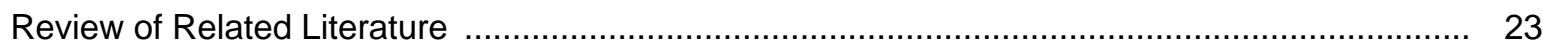

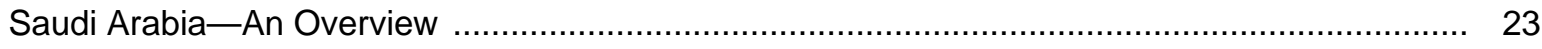

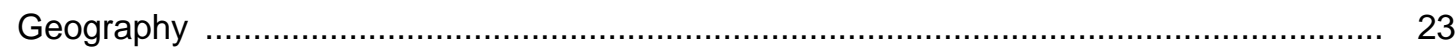

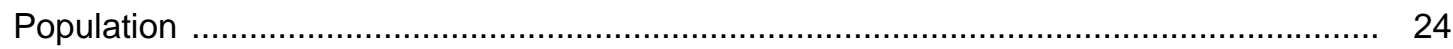

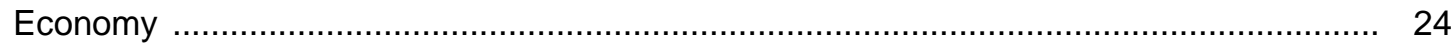

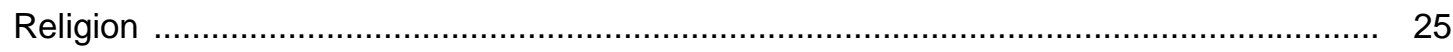

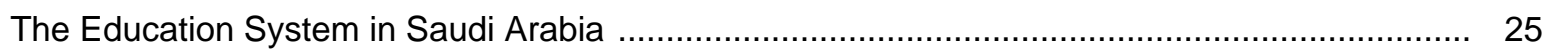

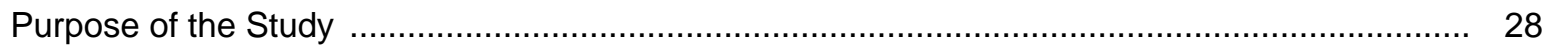

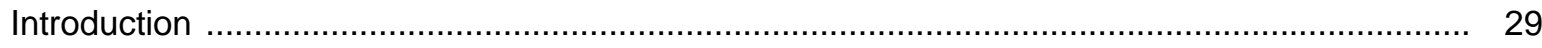

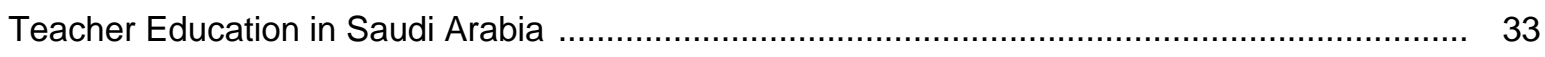

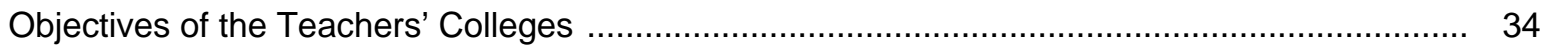




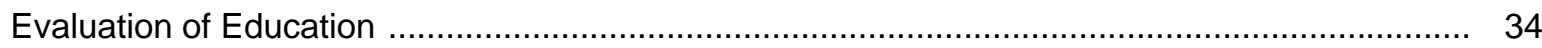

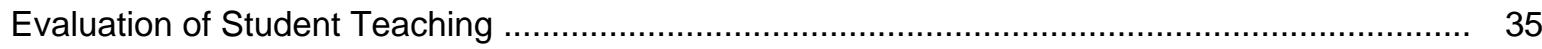

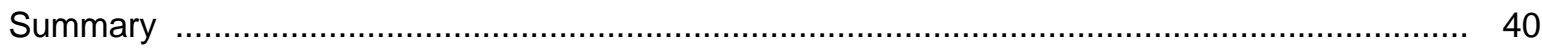

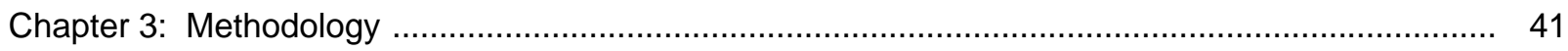

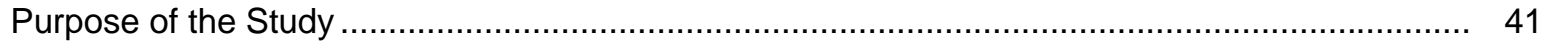

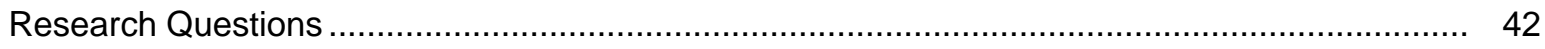

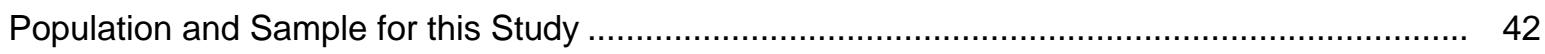

Survey Instrument: Design and Development ................................................................ 43

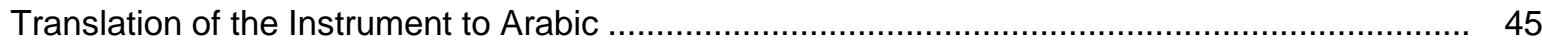

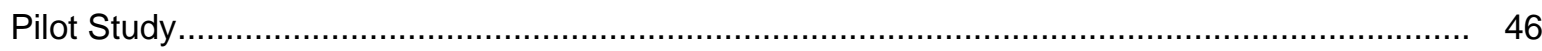

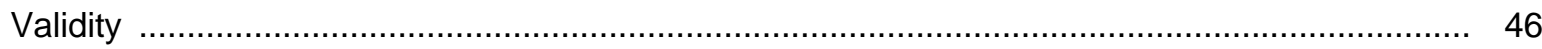

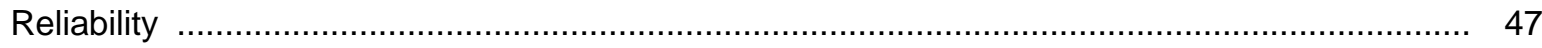

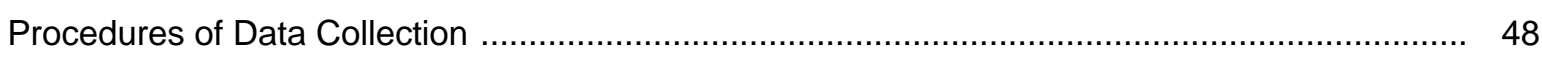

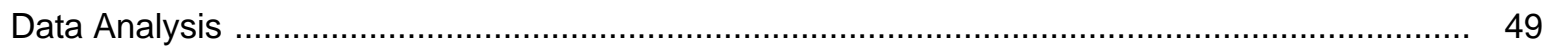

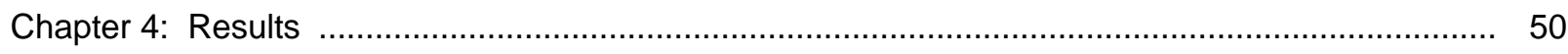

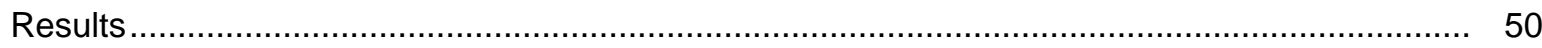

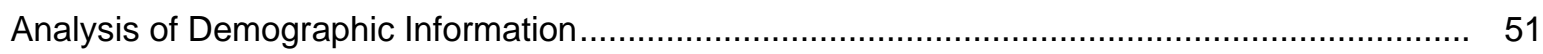

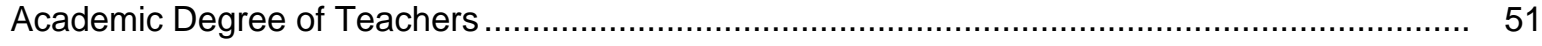

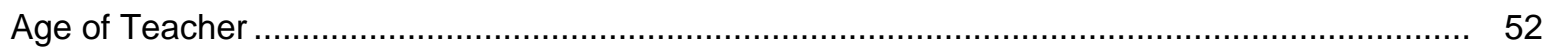

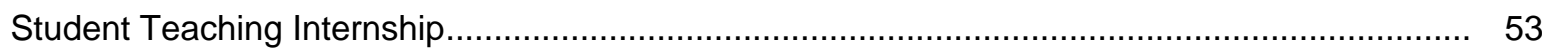

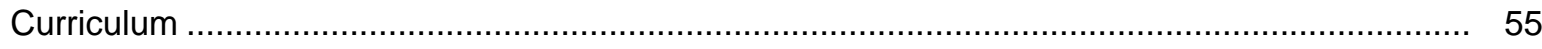

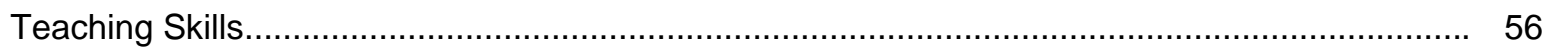

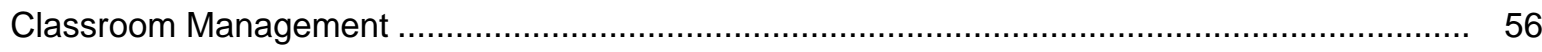

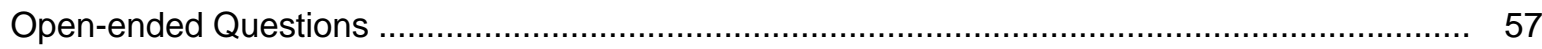

Chapter 5. Summary, Findings, Conclusions, and Recommendations ...................................... 63

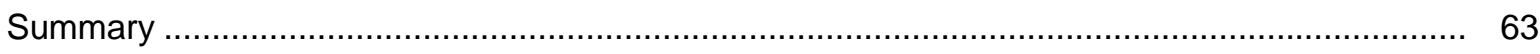

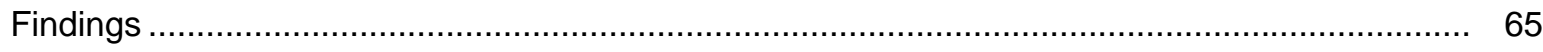


Limitations and Directions for Further Research .............................................................. 68

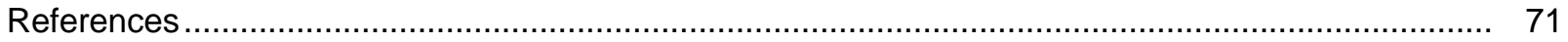

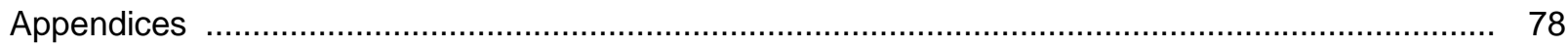

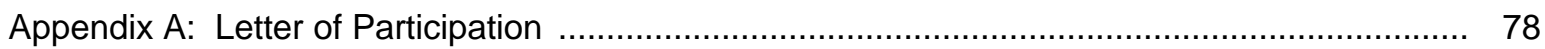

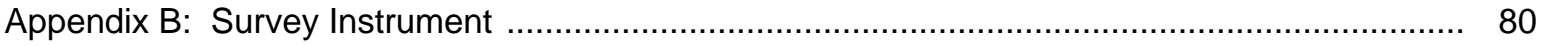

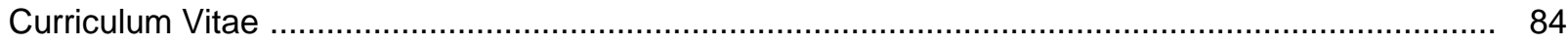




\section{List of Tables}

Table 1: Tabouk College General Required Courses ....................................................... 10

Table 2: Education Required Courses ...................................................................... 13

Table 3: Social Studies Required Courses................................................................ 15

Table 4: Stages of the Education System in Saudi Arabia................................................... 27

Table 5: Relation Between Research Questions and Items.................................................. 44

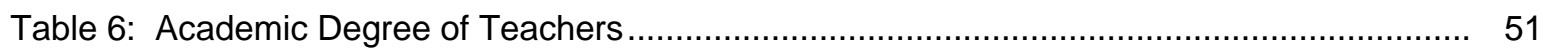

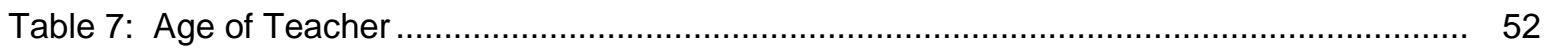

Table 8: Number of Years' Teaching Experience ......................................................... 52

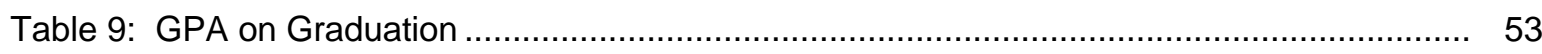

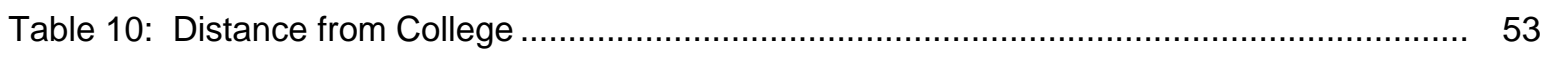

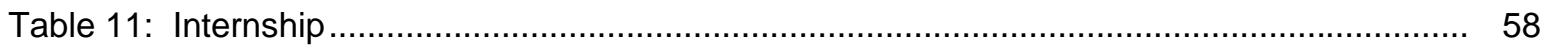

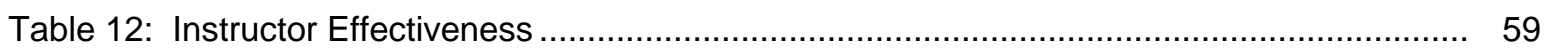

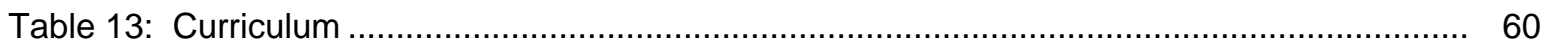

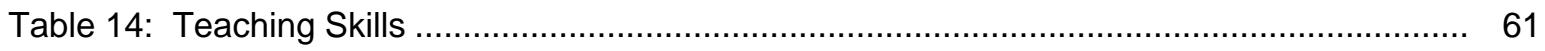

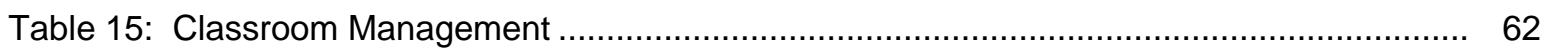




\section{CHAPTER I}

Introduction

Introduction and Statement of the Problem

Concerns in Saudi Arabia regarding improving the quality of teacher education have led to widespread calls for reform, change, innovation, or improvement in education (Al-Salloom, 1991). These are linked in one way or another to improvement in teacher education. It is through teacher preparation programs that new knowledge, skills, and values can be passed on to the younger generation. This is why when education policy is questioned, teacher education is often blamed for shortcomings in the system. Studies have shown that the quantity and quality of public education may depend both directly and indirectly on the quantity and quality of teacher preparation programs (Goodlad, 1990, Judge, 1990, \& Pearson, 1989). Educators and laymen would agree with the contention that improvement in teacher education is needed. This is so because there is an almost universal belief that education is a useful and powerful instrument for social development. This means that education is not, and should not be perceived as, merely a tool for the transmission of local or national cultural heritage, tradition, and values. Improving teacher education is a comprehensive goal. It deals with both pre-service and in-service teacher education.

In-service education in Saudi Arabia has sought to address the needs of both teachers and other educational personnel. The in-service education for the elementary teacher will be the primary concern. The need for in-service teacher training emerged as a result of a combination of the low status of Saudi elementary teachers who were ill-prepared for the responsibility of educating the youth of an entire nation and the continuous need to provide them with new knowledge, skills, and techniques in order to achieve competency. In a study conducted to identify ways of increasing enrollments, Al-Dayil (1979) found the participants of his study strongly in favor of further training. 
Stedman (1980) has stressed the necessity of improving the quality of instruction in elementary and secondary schools. He indicates that the improvement of quality of elementary and secondary education:

... Is appropriate and necessary for a number of reasons, including two of central importance. First: the quality of higher education cannot be divorced from the quality of schools that prepare entering freshmen. Second: higher education produces the teachers and administrators for our elementary and secondary schools (Stedman, 1980, p.5).

As a developing nation, the Kingdom of Saudi Arabia pays a great deal of attention to education in general and to teacher preparation in particular. Snyder (1963) indicated that during the ten years previous of 1952-1953, the number of public schools in Saudi Arabia tripled. The student enrollment increased well over three times and the number of teachers increased five times. Snyder added that "no problem in Saudi Arabia looms larger than the quantity of education available for the next generation" (Snyder, 1963, p. 69).

The Kingdom of Saudi Arabia's struggle to improve the quality of education can be traced back to the second development plan (1975-1980), which put emphasis on the process of training teachers. The goal was to enable the teacher training programs to meet all requirements for elementary teachers through the expansion of the secondary level institutes and establishing 16 education colleges for teachers. The Ministry of Education's commitment to improve teacher education continued into the third developmental plan (1980-1985) with regard to the improvement of instruction. A key project was the establishment of an education development center within the Ministry of Education" (Ministry of Planning, 1980, p. 307). The above quotation shows that the Saudi government pays considerable attention to methods of improving the quality of teacher education.

The Saudi Arabian government has established a strong system to prepare good teachers. The most important aspects of this development are the expansion of teacher preparation programs, which varied according to school demands from the elementary to the high school 
stage and for both males and females. The education policy in Saudi Arabia is directed by Islamic law; therefore, the Ministry of Education adapted the western models of teacher education to satisfy the social value system, which requires the segregation of male and female students.

Teacher education has responded to the improvement requirement and has gone through huge modifications during the last decade (Ministry of Planning, 2000). Improving teacher education programs requires evaluating these programs. Teacher preparation programs success and teaching success are closely related. Evaluation of teacher education programs should give considerable attention to the student teaching program, which is the most essential and beneficial component of any teacher preparation program.

The evaluation of a teacher's professional development and the need for in-service programs can improve his ability to teach. In a study conducted to determine what kinds of inservice activities were most needed by Indiana social studies teachers, Rhodes and Smith (1975) found that "classroom technique stood out as the area of greatest interest for in-service activities" (p. 8). Bennie (1966) puts much emphasis on the process of evaluating the student teaching experience and considered it as an essential step for teacher improvement. He indicated that if the prospective teacher is to improve in his personal and professional competencies, "it is essential that proper evaluation of his growth be incorporated into the student teaching experience as a planned and integral part. He added that evaluation in student teaching means the mutual analysis of success and failures and the identification of the causes of each with an eye toward the continued improvement of the student teacher in his teaching role" (Bennie, 1966).

Social studies teachers prepare the future generation. The preparation of these teachers should reflect the needs of future citizens. Ochoa (1988) believes that the thinking skills which are so essential for students to develop are one of the most important things to be included in teacher preparation. Teachers need to be prepared to teach issues in a manner that allows them to adapt to the classroom situation and respond to the needs and vital interests of students. Effective citizenship education in schools requires teachers who have studied in an effective 
citizenship education program (O'Connor, 1988). In addition, teachers need assistance, skills, and materials in order to produce effective learning (Hepburn \& Keach, 1974).

The preparation of the elementary teacher is needed for stimulating the child's potential. The child's potential can be stimulated if elementary school teachers are trained in competencies and skills related to these potentialities (Hamden, 1981, p. 18). Stedman (1980, p. 3) indicated that evaluating the collegiate programs that prepare teachers is an important step in improving quality. He also stated that program evaluation typically goes beyond assessment of minimum standards to a more comprehensive review of the strength and weaknesses of a program. The effectiveness of the products of the education activities and the relationship of the program and specific characteristics of faculty, student, curricula, facilities, and resources available for program improvement also include the energy, competence, and vitality of program leadership (Stedman, 1980 , p. 6). So, the important strategy for evaluating a teacher education program is to measure the effectiveness of the quality of the performance of its graduates in real settings, which are the classroom and the school. This shows that student teaching programs should be carefully planned so that they produce qualified and competent teachers.

The social studies student teacher training program at Tabouk Teachers' College has not been evaluated. Thus, this becomes the topic and problem of this research.

\section{Background of the Problem}

The education system places considerable attention on student teaching because it represents the area of highest importance in educational improvement. Educational experts' demand for better teachers continues to increase student teacher quality; more and more attention is being directed toward college and university programs by means of which young men and women prepare for teaching. These programs offer varying opportunities for one to acquire a liberal or general education through the study of the humanities, the arts, the sciences, mathematics, health and the social sciences. (Merrill, 1967)

Razik (1992) has worked closely with policy makers in countries like Oman and Qatar and makes the point that the states of Gulf Cooperation Countries face some problems today in 
teacher education such as the problems faced in American teacher education. There are no tight research pacemakers that can be personalized into teacher education programs in the states of Gulf Cooperation Countries (GCC). Thus far, research in education in the GCC ministries of education has been commissioned by a study concerning who is coming to certain schools and why, as well as developing trends and personal correlations (Razik, 1992).

Judge (1990) wrote about the British case and pointed to the important role of teacher education in educational reform: The education and training of teachers are at the very heart of the current reform of British education and exemplify the paradoxes and tensions contained within the reform. It is international truism that successful change in education depends on the active cooperation of talented and committed teachers. For that reason, able people must become teachers and commit themselves wholeheartedly to the improvement of schooling. The Education Act for England and Wales of 1988 will remain a piece of inspirational legislation and nothing more. The critical task for the rest of this century will be match the output of the teacher education system (or systems) to the need of these schools as well as to retrain the teachers already working in them (Judge, 1990).

Al-Aklobi (1992) wrote about the attitudes of teachers and supervisors toward social studies education in boys' secondary schools of Saudi Arabia's eastern province. He concluded that the social studies curricula are not developed to assist young Saudi students in developing skills for living in the next century. He also indicated that textbook and instruction media were outdated and outmoded. Al-Aklobi also reports that:

1. Social studies teachers do not get the help and support that they should expect from their supervisors. This is probably due to the heavy administrative load placed on supervisors. Supervisors' visits to their teachers are rare and when such visits occur, most supervisors come to deliver new instructions to the teachers and have no time for observing teachers or discussing teachers' problems. 
2. Results and recommendations of previous studies have not received enough attention from the Ministry of Education or have been put at a low priority by the Ministry.

Dover (1964) stated explicitly the significance of student teaching in testing the ideas and applying and synthesizing the theories and knowledge the student teacher had acquired in college courses. He pointed out that since the student teaching experience usually comes near the end of the undergraduate program for the professional and academic preparation of teachers, it furnished a very important opportunity for synthesis and application of theoretical learning that has been provided through course work. Thus, the concepts, values and skills which have been learned in a more or less theoretical way through course work may be applied and made more valuable to the prospective teacher (Dover, 1964).

Al Asem (2003) pointed out that the evaluation technique for rating the teachers' performance on the basis of classroom observation is not a new phenomenon in the education system, but is in fact a normally used, integral component of the educational evaluation system. It is interesting to note that some studies on the validity of the evaluation system reveal a lack of agreement between participants and supervisors regarding judgment on teacher effectiveness and the level of student learning (Medley \& Coker, 1987).

Another study conducted by Krustchinsky and Moore (1981) pointed out that numerous educators have considered classroom teaching experiences to be of a valuable benefit to teacher preparation programs. Likewise, many teachers would indicate that student teaching experiences were the most beneficial part of their educational training (Krustchinsky \& Moore, 1981).

Many studies have emphasized the importance of student teaching and have shown that it furnishes the student teacher with the competence, courage, and confidence she/he needs for effective teaching in the classroom. Brown (1962) indicated that one teacher, with no student teaching experience and fearful of a recurrence of the discipline problems of his first year of teaching, admitted that he did not have the courage to try a film in his fifth grade classroom until his third year of teaching or to attempt a unit with his class until the middle of his fifth year of 
teaching. The above statements show that there is agreement concerning the importance of student teaching programs as a complete part of teacher education and preparation. This shows that teacher preparation is beneficial for both the teachers and learners. Student teaching introduces the prospective teacher to the skills, knowledge, experience, and methods needed for effective teaching and helps them to develop competencies needed in harnessing and utilizing academically acquired skills and knowledge in an actual teaching setting.

Fortunately, student teaching is an accomplished part of teacher preparation in Tabouk Teachers' College. It is realized there that preparing a successful and qualified elementary teacher is imperative.

The elementary stage is very important because of the sensitivity and significance of the elementary schooling, which represents the first formal schooling that individuals experience in their education careers; it is also the basis for the following stages of schooling. If this stage of pupils' education is sound, it is expected that they will positively benefit from this schooling and successfully pursue the following stages. In other words, the more effectively and soundly the students at the elementary stage are prepared, the more success they are likely to achieve as they maintain their schooling. This indicates by implication that the better elementary school teachers are prepared, the more effective the elementary school is likely to be and, consequently, the more success the students are likely to achieve. Hamdan indicates that "a child's potential can be stimulated if elementary school teachers are trained in competencies and skills related to their potentialities" (Hamdan, 1981, p. 18).

Teachers' college programs in Saudi Arabia place considerable emphasis on the process of preparing their students for teaching, so students have to pass the class, C\&l 499: Practice Training, before they graduate. They take this class during the last semester of their program. Student teaching is considered the apex of the teacher education programs. Therefore, the program of student teaching must be planned in a way which will make the experiences introduced more interesting and skillful and help the student teacher understand the reality of schools and of teaching as a noble and sensitive profession. The student teaching experience 
must also help him assess his abilities, aptitudes, and skills. This self-evaluation may enable the student teacher to decide whether to pursue a career in teaching or not. The education revival in Saudi Arabia is still in its early stage. There is a need to place more enthusiasm on the process of teacher preparation programs, which must be comprehensively evaluated (Ministry of Education, 2001).

Teachers need to be prepared to teach issues in a way that allows them to adapt to the classroom situation and respond to the needs and vital interests of students. Effective citizenship education in schools requires teachers who have studied in an effective citizenship education program (O' Connor, 1988).

It is interesting to briefly observe what seems to be important in the preparation of social studies teachers in other countries. In Sweden, teachers must have a good foundation of knowledge about how they convey that knowledge (Blom, 1988). In Nigeria, social studies teachers focus on the areas of reflective inquiry, citizenship education, critical thinking, social issues and problems, global perspective, and strategies. Adeyemi (1989) concludes his discussion of the preparation of social studies teachers in Nigeria by saying that these teachers "must be pleasant, confident and reliable teachers. Above all they must be reflective in their thinking and must be able to serve their country effectively" (p. 204).

Early field experiences are considered part of the curriculum in teacher preparation programs. Such experiences take different forms and include varied activities to prepare prospective teachers for the next level (student teaching), which is usually the final stage in the teacher preparation program.

Early field experiences usually take place in school settings before student teaching (Applegate, 1986). Planning teacher education programs should take into account the necessity of helping students make the transition between taking courses at college and assuming complete responsibility for the classroom, including the transition from theory to practice. These programs should help pre-service teachers bridge the gap between wanting to teach and being able to teach, or learn about teaching and practicing (Conant, 1964; Dueck, et al., 1984). 


\section{Tabouk Teachers' College}

Tabouk Teachers' College is one of 17 colleges found in Saudi Arabia. It is located in Tabouk City in the Tabouk Area. Tabouk Teachers' College was established in August 1987 under the name of Tabouk Teachers' College.

Tabouk Teachers' College is the only one in the Tabouk Area. Tabouk Teachers' College serves as the potential teacher training institution for elementary school teachers. About 700 students are admitted to Tabouk Teachers' College each year, totaling about 2,700 students in any given year. Their program addresses the objectives of Saudi educational policy, which is designed to ensure that education abolishes illiteracy among Saudi adults.

The Tabouk Teachers' College in Tabouk City includes 11 departments:

1. Islamic Studies

2. Art Education

3. Science

4. Arabic Language

5. Social Studies

6. Physical Education

7. Mathematics

8. Psychology Education

9. Curriculum and Instruction

10. Computer Science

11. English Language

There is also a center for training school principals. The faculty totals 108 members. Table 2 provides a list of the required courses for students in Tabouk Teachers' College. 
Table 1. Tabouk College General Required Courses

\begin{tabular}{|c|c|c|c|}
\hline Course Number & Title & $\begin{array}{l}\text { Semester Credit } \\
\text { Hours }\end{array}$ & Attendance Hours \\
\hline $141 \mathrm{SS}$ & $\begin{array}{l}\text { The Prophetic } \\
\text { Biography }\end{array}$ & 2 & 2 \\
\hline $142 \mathrm{MA}$ & Algebra & 2 & 2 \\
\hline 103E & English & 2 & 2 \\
\hline 101ARB & $\begin{array}{l}\text { Arabic Grammar } \\
\text { Practical }\end{array}$ & 3 & 3 \\
\hline $101 \mathrm{CM}$ & General Chemistry & 3 & 3 \\
\hline 101 IS & Altajweed & 3 & 3 \\
\hline $101 \mathrm{PYO}$ & School Health & 1 & 1 \\
\hline 101 IS & Islamic Faith & 2 & 2 \\
\hline 101PE & Physical Education & 2 & 2 \\
\hline $171 \mathrm{SS}$ & $\begin{array}{l}\text { Saudi Arabia } \\
\text { Geography }\end{array}$ & 3 & 3 \\
\hline 105 IS & Holy Quran Science & 2 & 2 \\
\hline 104ARAB & Language Skills & 2 & 2 \\
\hline 102ARAB & Writing Skills & 2 & 2 \\
\hline
\end{tabular}




\begin{tabular}{|c|c|c|c|}
\hline $102 \mathrm{PE}$ & $\begin{array}{l}\text { Physical Education } \\
\text { for Kids }\end{array}$ & 2 & 2 \\
\hline 102 IS & Good Recitation & 1 & 2 \\
\hline 103 IS & $\begin{array}{l}\text { Good Recitation and } \\
\text { Memorizing (1) }\end{array}$ & 1 & 2 \\
\hline 104 IS & $\begin{array}{l}\text { Good Recitation and } \\
\text { Memorizing(2) }\end{array}$ & 1 & 2 \\
\hline 106 IS & $\begin{array}{l}\text { Holy Quran } \\
\text { Explication }\end{array}$ & 2 & 2 \\
\hline 103 IS & $\begin{array}{l}\text { Religious } \\
\text { Observances } \\
\text { Jurisprudence }\end{array}$ & 2 & 2 \\
\hline 104 IS & Islamic Traditions & 2 & 2 \\
\hline 105 IS & $\begin{array}{l}\text { Intro to Islamic } \\
\text { Economics }\end{array}$ & 2 & 2 \\
\hline 103ARB & Arabic Literature & 3 & 3 \\
\hline 105ARAB & Arabic Calligraphy & 1 & 1 \\
\hline 172 SS & Saudi Arabia History & 2 & 2 \\
\hline $122 \mathrm{MATH}$ & $\begin{array}{l}\text { Geometry and } \\
\text { Conversions }\end{array}$ & 3 & 4 \\
\hline 200MATH & Math Lab & 1 & 2 \\
\hline 120MATH & Analytic Geometry & 2 & 2 \\
\hline
\end{tabular}




\begin{tabular}{|l|l|l|l|}
\hline & and Algebra & & \\
\hline $190 \mathrm{MATH}$ & Computer Science & 2 & 2 \\
\hline 101 PHYSICS & General Physics & 3 & 4 \\
\hline $101 \mathrm{BOY}$ & General Biology & 3 & 4 \\
\hline $101 \mathrm{HELTH}$ & School Health & 1 & 1 \\
\hline $100 \mathrm{ART}$ & Intro to Artistry & 2 & 2 \\
\hline $101 \mathrm{ART}$ & Intro to Art & 2 & 2 \\
& $\begin{array}{l}\text { Appreciation and } \\
\text { Criticism }\end{array}$ & & \\
\hline
\end{tabular}

(Tabouk Teachers' College Bulletin, 2005, p. 267)

Students who specialize in Social Studies as their major field must complete the following courses described in Table 3. Table 4 displays electives. 
Table 2. Education Required Courses

\begin{tabular}{|c|c|c|c|}
\hline Course Number & Title & $\begin{array}{l}\text { Semester Credit } \\
\text { Hours }\end{array}$ & Attendance Hours \\
\hline 101EDU & $\begin{array}{l}\text { Intro to General } \\
\text { Education }\end{array}$ & 1 & 1 \\
\hline 102EDU & $\begin{array}{l}\text { Intro to Islamic } \\
\text { Education }\end{array}$ & 2 & 2 \\
\hline 103PSYC & $\begin{array}{l}\text { Educational } \\
\text { Research }\end{array}$ & 2 & 2 \\
\hline 111PSYC & $\begin{array}{l}\text { Educational } \\
\text { Psychology }\end{array}$ & 3 & 3 \\
\hline 201EDU & $\begin{array}{l}\text { Educational } \\
\text { Evaluation }\end{array}$ & 2 & 2 \\
\hline 202EDU & $\begin{array}{l}\text { Education System in } \\
\text { Saudi Arabia }\end{array}$ & 2 & 2 \\
\hline 211PSYC & $\begin{array}{l}\text { Development } \\
\text { Psychology }\end{array}$ & 2 & 2 \\
\hline 303PSYC & $\begin{array}{l}\text { School } \\
\text { Administration }\end{array}$ & 2 & 2 \\
\hline 311PSTC & Student Guidance & 2 & 2 \\
\hline $331 \mathrm{C \& I}$ & $\begin{array}{l}\text { Elementary } \\
\text { Education Curriculum }\end{array}$ & 2 & 2 \\
\hline $332 \mathrm{C} \& \mathrm{I}$ & $\begin{array}{ll}\text { General Teaching } \\
\text { Methods }\end{array}$ & 2 & 2 \\
\hline
\end{tabular}




\begin{tabular}{|l|l|l|l|}
\hline 344C\&I & $\begin{array}{l}\text { Social Studies } \\
\text { Teaching Methods }\end{array}$ & 2 & 2 \\
\hline 401SPED & Special Education & 2 & 2 \\
\hline 402C\&I & $\begin{array}{l}\text { Adult Education and } \\
\text { Illiteracy }\end{array}$ & 2 & 2 \\
\hline 333C\&I & Extra-Curricula & 2 & 1 \\
\hline 100TE & $\begin{array}{l}\text { Technology } \\
\text { Education }\end{array}$ & 1 & 2 \\
\hline 200TE & $\begin{array}{l}\text { Educational Media } \\
\text { Production(1) }\end{array}$ & 1 & 2 \\
\hline 201TE & Technology Use & 2 & 8 \\
\hline 300TE & $\begin{array}{l}\text { Educational Media } \\
\text { Production(2) }\end{array}$ & & 2 \\
\hline Practical Teaching $\& 1$ & 8 & & \\
\hline
\end{tabular}

(Tabouk Teachers' College Bulletin, 2005, p. 267-268) 
Table 3. Social Studies Required Courses

\begin{tabular}{|c|c|c|c|}
\hline Curses Number & Title & $\begin{array}{l}\text { Semester Credit } \\
\text { Hours }\end{array}$ & Attendance Hours \\
\hline $201 G$ & $\begin{array}{l}\text { Intro to Geography } \\
\text { Science }\end{array}$ & 3 & 3 \\
\hline $202 G$ & $\begin{array}{l}\text { Principle of Sociology } \\
\text { Science }\end{array}$ & 2 & 2 \\
\hline $211 G$ & $\begin{array}{l}\text { Intro to History } \\
\text { Science }\end{array}$ & 2 & 2 \\
\hline $221 G$ & $\begin{array}{l}\text { Geographic of } \\
\text { Climate and Plants }\end{array}$ & 2 & 2 \\
\hline $223 G$ & $\begin{array}{l}\text { History of The Old } \\
\text { Near East }\end{array}$ & 2 & 2 \\
\hline $232 G$ & $\begin{array}{l}\text { Practical Geography } \\
\text { and Mapping }\end{array}$ & 2 & 2 \\
\hline $242 G$ & $\begin{array}{l}\text { The History of The } \\
\text { Right-Guided Caliphs }\end{array}$ & 2 & 2 \\
\hline $243 G$ & $\begin{array}{l}\text { History of Alomoiah } \\
\text { Country }\end{array}$ & 2 & 2 \\
\hline $344 G$ & $\begin{array}{l}\text { History of Alabasiah } \\
\text { Country }\end{array}$ & 2 & 2 \\
\hline $345 G$ & $\begin{array}{l}\text { History of Maghreb } \\
\text { and Alandulus }\end{array}$ & 2 & 2 \\
\hline $350 G$ & $\begin{array}{l}\text { Economic } \\
\text { Geography }\end{array}$ & 2 & 2 \\
\hline
\end{tabular}




\begin{tabular}{|l|l|l|l|}
\hline $373 G$ & $\begin{array}{l}\text { The Region World } \\
\text { Geography }\end{array}$ & 2 \\
\hline $441 G$ & $\begin{array}{l}\text { Population } \\
\text { Geography }\end{array}$ & 2 & 2 \\
\hline $451 G$ & $\begin{array}{l}\text { History of Islamic } \\
\text { Civilization }\end{array}$ & 2 & 2 \\
\hline $474 G$ & $\begin{array}{l}\text { Arabic World } \\
\text { Geography }\end{array}$ & 2 & 2 \\
\hline $477 G$ & $\begin{array}{l}\text { History of Modern } \\
\text { Arab }\end{array}$ & 2 & 2 \\
\hline
\end{tabular}

(Tabouk Teachers' College Bulletin, 2005, p. 268)

Purpose of the Study

The main purpose of this study was to analyze teachers' perceptions of the effectiveness of the Social Studies Student Teacher Training Program (SSSTTP) at Tabouk Teachers' College in Tabouk City. The researcher strongly believes in the importance of this field of study. Since the establishment of Tabouk Teachers' College, considerable attention has been given to the student teacher training program. While changes and additions have been made from year to year, they were not based on a reliable and comprehensive analysis of this program, but rather on oral or written suggestions from the college supervisors, the deans, the school principals, or the program directors. As I previously mentioned, the student teaching experience is the most important single experience in any teacher education program. This is true if these experiences are strong, beneficial, and well planned. When we would like the student teaching experiences to be effective, we have to analyze continuously and comprehensively.

Educators have pointed out that the main purpose of analyzing an educational or training program is to provide information for decisions about the program. This led to the consummation 
that well planned analysis is a careful procedure for improving the social studies student teacher training program in the Tabouk Teachers' College.

\section{Research Questions}

1. To what extent do teachers believe that the social studies program and courses taught at Tabouk Teachers' College prepared them for teaching social studies within the principles of Islam?

2. To what extent do teachers feel that the social studies program and courses taught at Tabouk Teachers' College prepares them for teaching in Saudi Arabia schools?

3. To what extent do teachers feel that the curriculum meets the needs of the Saudi society?

4. To what extent do teachers feel that the level of technology used at Tabouk Teachers' College prepares them to use technology in teaching?

5. To what extent does the social studies program as taught at Tabouk Teachers' College prepare teachers to use various classroom management techniques in their teaching?

6. To what extent are social studies graduates satisfied with their internship?

\section{Method}

The researcher, in this study, used the survey method to investigate and collect data needed to answer the research questions. It is hoped that the findings, suggestions, and recommendations of this study may help the directors and supervisors of these programs improve the quality and quantity of the educational experiences and activities provided by these programs to produce better teachers for Saudi Arabian schools.

Definitions and Goals of Social Studies

Some persons see social goals as the proper goals for schools. Goodlad (1979) notes that the function of schools reflects the needs and interests of society. Although schools are educational institutions, their social goals usually take precedence over their educational goals. 
Goodlad describes some of the goals for schooling, particularly in mastery of basic skills; intellectual development; enculturation; and development of autonomy, a sense of citizenship, self-concept and self-realization, and moral and ethical character.

While in school, students are expected to learn necessary knowledge and skills and to develop their intellectual ability. Learning in the classroom should include attention to events taking place in the world outside school. Schools should be considered a living social system which includes the study of issues, problems, and values of society. Massialas (1989) concludes that schools need to provide students with "tools that enable them to meet the daily challenges in their environment and to take hold of their own lives and make prudent decisions" (p. 175). The school's job, then, is to provide students with the experience of life outside these schools and to help them see the meaning of these events. As Bode (1940) emphasizes, students must be acquainted with what is going on in their society. Evans (1989a) remarks that in John Dewey's view, the aim of schooling is to prepare citizens who will be worthy, harmonious, and loving toward his society. Kaywell and Carroll (1988) suggest that students should be prepared from an early stage to be able to understand and become aware of their environment (people, earth, and resources).

\section{Definitions of Social Studies}

Hertzberg (1981) notes that Wesley is considered one of the leaders in social studies education. He was the first person to define the term "social studies": "the social science simplified for pedagogical purposes" (Wesley, 1942, p. 6). A second definition of social studies is "a unitary field comprised of materials from various disciplines, regardless of discipline boundaries, which is centered on the needs of students and society". A third definition, which is rarely used today, "designates almost any school subjects as a 'social study' provided it is somehow related to social purpose or social utility" (Hertzberg, 1981, p. 2). A fourth definition is the term "social sciences," which is also used to refer to social studies. Hertzberg notes that the last definition emphasizes the social science aspect of Wesley's definition, but neglects the pedagogical purposes. 
Barth and Shermis (1980) report that the field of social studies is a creation of the twentieth century. Before this time, neither the term "social studies," nor anything similar to the present-day social studies in schools existed. They state: "Wesley and others in the social studies movement of the teens, 20 s and 30 s, conceived of the social studies not as separate disciplines but as integrated disciplines for the purpose of solving problems. Wesley recognizes his debt to Dewey and, in fact, it was Dewey's formulation of experience, which became a considerable attraction for social studies educators and others in education for many decades" (p. 5).

The most influential report in the history of social studies was that of the National Educational Association Committee in 1916. It was part of the committee's efforts known as "The Commission on the Reorganization of Secondary Education." In this report, the term "social studies" was recognized for its role in activities involving citizens in the development of the conditions of contemporary society (Hertzberg, 1981; Barr et al., 1978. Barr et al. note that " the committee recommended that students were to become effective citizens not by memorizing historical content but by practicing decision-making in their daily lives" (p. 105).

The movement to reform the field of social studies was strongly evident in the 1960 s and 1970s, along with reform movements in other fields in schools and classrooms. Hertzberg (1981) argues that during this movement, reformers assumed that they knew the problems which needed to be addressed and even the results of proposed changes. These assumptions, however, proved to be incorrect, and the outcome of the movement harmed schools and classrooms. In the 1980s, the trends of reform took the form of research coherence, "a reflection of the intense yearning in the larger society for understandable explanations of the perplexities of the 1970s" (p. 183). Barr et al. (1978) provide a version of the recent and most common definition of social studies:" The social studies is an integration of social science and humanities for the purpose of instruction in citizenship education" (p. 18). 
The Goals of Social Studies

Pahl (1990) discusses some aspects of the goals of social studies throughout history. He notes that in the 1930 s and 1940s, the goal was to create programs which would help students during war time to become "propaganda resistant, which led to today's ideas on critical thinking" (p. 271).

Generally, social studies is expected to provide students with the knowledge, skills, and attitudes needed to prepare them to grow and live effectively in their society (Gross et al., 1978). More specifically, at all levels of education, students need to be prepared with suitable knowledge, skills, understanding of world events, sense of the impact of issues and problems (local and global) on their daily lives, and the interrelatedness of the world's people and cultures (NCSS, 1982). Therefore, the goals of social studies are appropriate if they develop within social studies students the characteristics suitable for a citizen of the early twenty-first century.

Such a citizen

- $\quad$ is well informed on a broad range of global topics and issues

- is a critical thinker

- $\quad$ seeks justice and equality for all

- sees interdependence and cooperation as a way of life

- is an active participant in society and takes responsibility for his or her actions

- $\quad$ sees change as a constant that can be managed and directed

- views learning as a lifelong pursuit rather than a fixed period of instruction in a formal setting (Cogan, 1989, p.243)

\section{Definition of Terms Used in Saudi Arabia}

Social Studies: Hertzberg (1981) notes that Wesley is considered one of the leaders in social studies education. He was the first person to define the term "social studies": "the social science simplified for pedagogical purposes" (Wesley, 1942, p. 6). A second definition of social studies is a unitary field comprised of materials from various disciplines, regardless of discipline boundaries, which is centered around the needs of students and society. A third definition, which 
is rarely used today, "designates almost any school subjects as a 'social study' provided it is somehow related to social purpose or social utility" (Hertzberg, 1981, p. 2). A fourth definition is the term "social sciences," which is also used to refer to social studies. Hertzberg notes that the last definition emphasizes the social science aspect of Wesley's definition, but neglects the pedagogical purposes.

Student Teacher: The student teacher is someone who is learning to teach at a cooperating school under the supervision of a cooperating teacher. This can be also be defined as an internship.

College Supervisor: College members who are responsible for the supervision of student teacher activities and the relationship and conditions under which new students carry on their work are college supervisors (Johnson \& Anderson, 1971).

Cooperating Teacher: The regular classroom teacher at the cooperating school who supervises the student teacher.

Observation: Observation is the first step in student teaching, when the student teacher is given the chance to visit the classroom to be able to observe cooperating teachers and the students in real teaching situations.

Cooperating School: The cooperating school is an elementary school, which provides facilities for practical lab experiences for college students.

Teachers' College: This College prepares and offers courses after high school or its equivalent for persons who wish to teach in elementary and middle schools. This college is one of eighteen types of colleges to increase the level of education of teacher training.

\section{Assumptions of the Study}

The research in this study assumed the following:

- Survey methodology was reliable and that procedures for obtaining the information required by the research questions were valid and that the answers to the survey were complete and honest. 
- The personnel of the educational administration in the subject schools would cooperate with the researcher and provided him with the needed information from their records concerning a selected sample of the participants who graduated from Tabouk Teachers' College.

- Practice can be informed by, and improved with, valid research.

Limitations of the Study

The study analyzed the Social Studies Student Teacher Training Program (SSSTTP) at Tabouk Teachers' College; so, it was limited to:

- Only male subjects attend teacher training at Tabouk Teachers' College.

- The result recorded on the respondents' interpretation of the survey items and their integrity in responding to these items, and

- Results may not be generalized to other student teaching programs in other colleges in Saudi Arabia.

\section{Summary}

Chapter I presented the background, the problem, purpose, a description of the Tabouk Teachers' College, research questions and method, population, assumptions, and limitations for this study. 
Chapter 2

Review of Literature

\section{Review of Related Literature}

As discussed previously, the purpose of this study was to analyze teachers' perceptions of the effectiveness of the Social Studies Teacher Training Program (SSSTTP) at Tabouk Teachers' College in Tabouk City. This chapter presents the literature related to the research problem. The review of the literature presents an introduction to teacher education programs in Arab countries and teacher education in Saudi Arabia, objectives of Tabouk Teachers' College, evaluation of student teaching, and the importance and objectives of the student teaching experience.

\section{Saudi Arabia -An Overview}

The Kingdom of Saudi Arabia engages most of the Arabian Peninsula. Prior to the arrival of Ibn Saud Abdulaziz in 1902, it consisted of many districts and sheikdoms. Ibn Saud controlled Riyadh, the capital at the time, and later he opened AlHasa, Al Hijaz in 1925, and also other regions. He became king of Saudi Arabia in 1932, and it was at this time that Saudi Arabia became a unified country.

\section{Geography:}

Saudi Arabia has an area of 872,722 square miles, making it one of the largest countries in the Middle East. It is bordered by the Arabian Gulf, Qatar, and the United Arab Emirates to the east, Oman and Yemen to the south, the Red Sea and Gulf of Al-Aqaba to the west, and Jordan, Iraq, and Kuwait to the north. Saudi Arabia is composed of several areas: Najed, Hejaz, Asir, and Hasa, plus the southern and northern desert areas. However, it has a bountiful coastal plain 10 to 40 miles wide, bordered by steep mountains that rise to over 9,000 feet near Yemen. The Nagel plateau is bordered by the great desert areas of Nefud in the north, Dahna and Nefud in the east and the Rub Al-Khali (Empty Quarter) in the south. The location of Saudi Arabia at 1632 latitudes north is an indication that its climate is hot. However, there is an interesting variation 
in the climate among the various regions of the country. Temperatures also vary widely throughout the year. The north and central areas of the country have a continental climate.

Summers are hot, with temperatures often reaching $120^{\circ}$ Fahrenheit during the day, although it drops rapidly at sunset in the desert interiors. Winter is very cold, especially in Tabouk City, sometimes as low as -20F. Summers can be annoying, with temperatures averaging $100^{\circ}$ Fahrenheit, while the humidity is usually in the high 90 s.

The mountainous areas of the southwest enjoy a distinctly milder climate than the rest of the country and receive a great deal more rainfall. A notable result of the sparse rainfall is that the kingdom contains no permanent rivers or bodies of water. The annual average of precipitation ranges from three inches to twenty inches in the mountains of the country's southwest are (Johany, 1986).

\section{Population:}

According to the nationwide population census conducted in 1992, the total population of Saudi Arabia was 16.9 million. However, the population increased to 23.3 million by 2003 , according to the central Department of statistics in Saudi Arabia (Saudi Press Agency, 2003).

\section{Economy:}

Saudi Arabia has the largest reserves of petroleum in the world ( $26 \%$ of the proved total), ranks as the largest exporter of petroleum, and plays a leading role in OPEC. The petroleum, which was discovered 1938 in the western province, is the mainstay of the country's economy. It is extracted at a rate of nine million barrels a day, giving the kingdom over 70 percent of its national income (Ministry of Planning, 2000). In addition Saudi Arabia has an abundance of mineral resources, including gold, silver, iron, and copper. The monetary unit of the country is the riyal, which is divided into 100 halalas. Saudi Arabia struggled to develop its economy, therefore the Kingdom's development has been overseen by a series of five-year plans:

First Development Plan: (1970-1975)

Second Development Plan: (1975-1980)

Third Development Plan: (1980-1985) 
Fourth Development Plan: (1985-1990)

Fifth Development Plan: (1990-1995)

Sixth Development Plan: (1995-2000)

Seventh Development Plan: (2000-2005)

(http://www.saudinf.com/main/e5.htm)

\section{Religion:}

"Religion for you and completed my favor unto, and have chosen for you as your religion Islam" (Quran: translation of the meaning, 5:4). Islam is an international religion, based on the surrender to God, who is one. The term, "Islam," meaning "submission," points to the fundamental religious creed, which dictates that a Muslim submit to the will of Allah by conforming inwardly and outwardly to His law.

Saudi Arabia has always been important to the world's Muslims because Islam's two holiest cities are located there: Makkah (Mecca). Makkah is Qibla (the direction towards the Holy Ka'ba; the place towards which Muslims turn their faces in prayer, namely, the holy Mosque in Makkah (Al-Maliki, 1995). In addition, Makkah is the birthplace of the prophet Mohammed, and Medina is where the prophet established the first community and laid the foundation of Islam.

\section{The Education System in Saudi Arabia}

Saudi Arabia is an old culture with a new governmental arrangement and new way of thinking about education. Saudi Arabia, in the twenty-first century, is rapidly developing an education technology.

The Ministry of Education was established in 1952. The main purpose of education in Saudi Arabia as stated in the general principles of education is "to have students understand Islam in a correct and comprehensive way of life, to plan and spread the Islam in a creed, to develop the society economically, socially, and culturally, and to prepare the individual to become a useful member in the building of his community" (Ministry of Education, 1974, p. 28).

The educational system in Saudi Arabia is based on the teachings of Islam, as stated in the educational policy acquainting the individual with his God and religion and adjusting his 
conduct in accordance with the teaching of religion, in fulfillment of the needs of society, and in achievement of nation's objection. The Islamic domination of the education system in Saudi Arabia may be summarized as three points:

1. The policy of the Kingdom of Saudi Arabia is based on Islamic rules and the educational system places emphasis on the Islamic religion. Islamic studies are basic in all elementary, middle, and secondary schools.

2. The Ministry of Education in Saudi Arabia controls every school district in the country and provides all facilities, teachers, salaries, buildings, etc.

3. Boys and girls in Saudi Arabia attend separate schools for religious reasons. The Ministry of Education serves both boys' schools and girls' schools. Education in Saudi Arabia is obligatory for all children until they finish the sixth grade. Education is free for all adults and children from kindergarten, elementary, middle, secondary, and university levels. The system of education in Saudi Arabia contains several features, which operate under the aegis of different government agencies (Ministry of Education, 1974, p. 34).

There are four stages of general education supervised and developed by the Ministry of Education in the Kingdom of Saudi Arabia for boys. The ministry established 40 education districts in different areas of the country to implement the education policy and programs, as well as to provide schools with equipment, materials, and designed activities.

There are four stages of general education supervised and developed by the Ministry of Education in the Kingdom of Saudi Arabia for boys. The ministry established 40 education districts in different areas of the country to implement the education policy and programs, as well as to provide schools with equipment, materials, and designed activities.

The type and method of schooling in Saudi Arabia closely follows the western education system and is comprised of several levels. Kindergarten is optional for children; however, the development of this type of education is still in progress, and is not yet considered an important part of the education system. The elementary stage contains six grades. The minimum age for a 
student to be enrolled at the elementary stage is six years. The students are evaluated by the teachers every week. According to that evaluation, the student will be pass or fail.

Students have to obtain the elementary school certificate to be entered in the intermediate stage, the second formal education system. This stage consists of three grades. The student must pass the year exams for each subject in each grade in order to progress to the next grade. The secondary stage contains three grades (See Table 5). To graduate, the student must complete the required subjects and pass their individual subject exam.

Table 4. Stages of the Education System in Saudi Arabia

\begin{tabular}{|c|c|}
\hline Stage & Grade \\
\hline Elementary Stage & K-6 \\
\hline Middle Stage & $7-9$ \\
\hline Secondary Stage & $10-12$ \\
\hline \multicolumn{2}{|c|}{ (Ministry of Education, 1978) } \\
\hline
\end{tabular}

Education in Saudi Arabia involves segregation of male and female students. The Ministry of Education applies the national program offered to male students with additional emphasis on women's concerns, such as sewing, women's health, life maturity, guidance, and house economy. It directs schools and programs at the elementary, middle, and high school levels. However, at secondary level, students beginning eleventh grade may choose between the science section and the art section. They study more subjects, such as sciences and mathematics, in the science section, and they study humanities in the arts section. Other subjects such as English, fine arts, and physical education are supplementary, designed to develop the individual interest of the students. There are also colleges and postgraduate levels in addition to other specialized training institutes such as nursing, tailoring, and teaching. The Ministry of Higher Education was established in 1975 to serve and direct the Kingdom's eight universities and colleges. 
The general Organization for Technical Education and Profession Training was established in 1975 to direct and implement the state manpower development plan and all related training centers and institutes designed to prepare capable and experienced workers. There are several types of educational programs such as technical industrial education, technical commercial education, technical agricultural education, vocation training centers, and secondary technical supervisors' institutes.

Al-Gamdi (1982) elaborated the goals of the Ministry of Education:

1. to train unqualified teachers already in the teaching force;

2. to retrain and rehabilitate those teachers and school administrators who have been inadequately prepared and /or those who possess low-level education certificates;

3. to provide public school personnel opportunities to upgrade their skill levels and raise their educational standards;

4. to provide for the development of the whole person as an individual member of the society at large;

5. to provide the teacher with an opportunity to keep abreast of developments in his subject matter area and acquire new teaching skills and methodology; and

6. to help public school personnel develop their capabilities in relating theory to practice (Al-Gamdi,1982, p. 69).

These goals concern the training of both teachers and administrative personnel.

Purpose of the Study

The purpose of this study was to analyze students' perceptions of the effectiveness of Social Studies Student Teacher Training Program (SSSTTP) at Tabouk Teachers' College. The researcher strongly feels the importance of this field of study. Since Tabouk Teachers' College was established, considerable attention has been given to the student teacher training program. Changes in the program have been based on oral or written advice from the college supervisors, the deans, the school principals, or program directors rather than from a comprehensive analysis of these programs. The student teaching experience is the most important single experience in 
any teacher education program. This is correct if these experiences are hard, advantageous, and well planned. For student teaching experiences to remain effective, they must be analyzed continuously.

Educators have pointed out that the main purpose of analyzing an educational or training program is to provide information for decisions about the program. This conducted to the consummation that well-planned analysis is a prudent procedure for improving the social studies teacher training program in the Tabouk Teachers' College.

Introduction

The researcher struggled to find literature related to this study and, in particular, to the evaluation of social studies student teaching programs in Saudi Arabia education colleges in general and specifically in the Tabouk Teachers' College. The researcher conducted a diligent search, but he found that no such study has been made in Tabouk Teachers' College which related to the social studies student teaching program.

Al-Ahmed's (1979) study focused on the professional preparation of teachers but failed to tell how graduates feel about the preparation they received in their subject area specialty. AlAhmad found evidence that teachers felt effectively prepared. Yet, he also concluded that the professional courses in education did not develop needed competencies of teachers to function effectively in the school. These conclusions seem contradictory and thus are of little help in understanding how teacher education programs might be improved.

Al-Wabli (1982) conducted a study to evaluate selected aspects of the secondary teacher preparation program at the Ummal-Qura University. His findings indicated that "there should be in-service education by the same classroom teachers and methods instructors who teach on campus to help beginning teachers" (p. 171). The researcher strongly endorsed in-service training as the most appropriate technique to develop increased competencies in teachers.

In another survey conducted by Shadly (1978) at Riyadh University, the researcher examined ongoing teacher training programs. The study indicated that the training program graduates lacked adequate preparation: "The in-service graduates lacked basic knowledge about 
learning theories, trend, issues, schools of thought, and methodology" (p. 104). Shadly recommended that the college of education together with the Ministry of Education provide a summer program and/or mini-courses and workshops to increase the knowledge of in-service graduates.

Generally, the idea of attending summer educational programs has gained some favor among Saudi teacher educators. Al-Ghamdi (1982) recommended that "summer programs can effectively meet the needs of rural teachers in remote areas of the country: Summer sessions should be reconsidered to provide in-service activities for rural and remote school teachers until in-service activities become available to them in their schools" (p. 165).

In 1966, Apple conducted a study investigating the effectiveness of the preparation of secondary teaching offered at North Park College. This study was focused on the evaluation of general education. Apple found that teachers were prepared effectively. In his study of Saudi Arabia male elementary teacher preparation programs, Hamdan (1981) described student teaching practice programs. He stated that "observations of other student teachers during their practice periods is the sole utilized technique in student teaching" (Hamdan, 1981, p. 96). He also noted that "student teaching is almost nonexistent in Saudi program practices (none of the universal elements utilized in other student teaching programs are practiced in Saudi preparation programs), except the utilization of observation and 12 teaching periods" (Hamdan, 1981, p. 99). He summarized that student teaching practices such as the provision of early, varied, and gradual experiences, interaction, analysis, simulations, team teaching, experience as teachers aides, microteaching, audio video taping, and internship do not exist in the reported Saudi elementary teacher preparation curricula.

Most of the teachers in elementary schools receive education equivalent to secondary school, and in some cases teachers have the degree from education colleges. In some Arab countries, such as Syria, Egypt, and Jordan, students are admitted to teacher education 
programs, which vary from three to five years. Three-year programs are concentrated in what is called teacher preparation institutes, while five-year programs are found in education colleges. This was based on the recommendation of the Arab Ministries conference held in Libya in 1970 (Mursi, 1981).

Nicklas (1976) conducted a study of the North Texas State University teacher education program. Fifty questions were used in a survey to obtain data identifying strengths and weaknesses of the teacher education program. The question contained several parts: background information, degree of satisfaction with professional education courses, and ratings of specific professional courses. The results showed that the majority of graduates believed that they were adequately prepared and that they were satisfied with the teaching profession. The results indicated that graduates considered the most important and strongest course of study in their preparation to be their student teaching experience.

Nicklas (1976) focused on selected teaching characteristics and professional education courses, but failed to describe which components of the area of specialization were most important. The study also failed to identify specific values and attitudes of graduates regarding these certain teaching characteristics and the professional courses.

In another study involving graduates with one and two years of teaching experience, Etim (1980) examined the programs of teacher preparation in several universities. Etim wanted to measure the effectiveness of the teacher education curriculum in the preparation of secondary teachers. A mailed questionnaire was used to identify weaknesses and strengths of the program. The respondents indicated that the strongest part of the program was their subject matter specialization. The weakest part of the program was in student teaching. Etim, however, concluded that $94 \%$ of graduates involved in the study were satisfied with the teacher preparation they received.

Dickenson (1980) examined the effectiveness of a teacher education preparation through the attitudes of graduates. Data were obtained from 1,057 returned questionnaires and analyzed through inferential statistics. The findings indicated that student teaching experiences and 
professional education courses were highly valued by graduates. Dickenson concluded that in general the attitudes of graduates toward their pre-service preparation were satisfactory. The attitudes of graduates with longer teaching experience were less favorable toward the program. This study focused on the effectiveness of education courses that prepare students for the profession. The study did not do an in-depth examination of teacher preparation courses in the area of specialization as a component in teacher preparation. It is important to know which courses in the area of specialty are more or less effective so that improvements can be made to the program.

In many Arab countries, there have been upgrading efforts in which teachers are required to have university certification from a professional program, such as that offered in order to teach in the public school. This is the case in Saudi Arabia, which began to take the quality of teachers into consideration after a long period of difficulty with teacher quality during the previous decades. For middle and high school teachers, the university degree is the minimum requirement for teaching. Many teachers at the secondary schools graduate from universities without experience, either theoretically or practically, in teaching. Al-Raway (1988) studied high school teachers in the United Arab Emirates in order to define the most important areas where teachers lack the previous preparation and concluded that: The most five needed competencies are as follows: ability to present lesson ideas clearly, maintaining good personal characteristics, ability to manage the classrooms, establishing and encouraging student moral and religious education, and ability to design a lesson plan" (Al-Raway, 1988). During the independence era, the Arab government employed many teachers who had little training, but with time, the demand for highlyeducated teachers soon became a major goal for the Arab government.

A study by Jensen (1971) which was replicated by Graff (1977) showed that the University of lowa teacher preparation program was viewed as effective based on the responses of 911 graduates. The purpose of these two studies was to evaluate the teacher education program as a step toward improving the program. Findings indicated that graduates were generally satisfied with their preparation. Graduates were most satisfied with methods courses, courses in audio- 
visual methods, student teaching, and evaluation of student progress. The only difference Graff (1977) found was that male enrollment in the program showed an increase from $34.6 \%$ in 1971 , revealed in Jensen's study, to $44.6 \%$ in 1976.

Both studies failed to reveal information skills graduates developed in the area of their teaching specialty. The studies did not indicate the degree of skills in teaching and knowledge which graduates believed they gained from their pre-service preparation.

Teacher Education in Saudi Arabia

Teacher education programs in Saudi Arabia began in the 1950s at Makkah City (AlSalloom, 1991). In 1964-1965, there were about 30 institutes for teachers. Since then the country has witnessed a very rapid expansion in this sector as a result of the huge development in education in all areas. Various programs of teacher education have been introduced to serve different interests and demands in the country (Al-Saloom, 1991).

In 1975-1976, teacher training institutions for elementary teachers extended to a total of 60 (including 30 for men and 30 for women) and were organized to train students for three years. The graduates were then channeled into the elementary schools. In 1977, colleges of education were established to provide qualified school teachers. Today, teachers at the primary school are required to have a bachelor degree in education.

Middle and high school teachers are graduates from this university with different subject preparation, although many of them join the teaching staff without training. The exception to this is those students who graduate from the college of education. In a short time, all teachers who have not received professional training at the college of education or teachers' colleges were required to take one year of postgraduate course work in order to be qualified for teaching in the schools. 
Objectives of the Teachers' Colleges

According to the Ministry of Education, the teachers' colleges were established to reach several objectives:

1. To prepare elementary school teacher educationally and academically.

2. To increase and to improve the experiences of secondary training institutes who have been working with teachers to reach improved teaching performance.

3. To improve and develop curriculum and instruction in the teachers' colleges.

4. To become involved in community development (Ministry of Education, 2000).

\section{Evaluation of Education}

In the past decade, studies on program evaluation increased, and budgets for evaluation have been increased as well. It is becoming common to find formal requirements that programs be routinely evaluated for their effectiveness (Rutman, 1980, p. 15).

Some studies on educational evaluation have been defined as "the process of making judgments about the merit, value, or worth of educational programs, projects, materials, and techniques" (Borg \&Gall, 1983, p. 733).

Wolf (1984) and Borg and Gall (1983) all discussed in detail the difference between evaluation, measurement, and research. Wolf points out that measurement "is the act or process of measuring. It is essentially an amoral process in that there is no value placed on what is being measured." He also added "in evaluation, quite the opposite is the case. The major attributes studied are chosen precisely because they represent educational values" (Wolf, 1984, p. 7).

Borg \& Gall discussed the differences between educational research and evaluation. They pointed out that "there is great degree of overlap between educational research and educational evaluation." They added that "yet there are important differences between the two fields in purpose" (Borg \&Gall, 1983, p. 737). They also described three differences:

- evaluation research is usually done by someone for a decision to be made concerning policy, management, or political strategy; in contrast, educational 
research is usually initiated by a hypothesis about the relationship between two or more variables,

- evaluation research is often done for limited purposes; in contrast, researchers are more likely to be interested in discovering widely applicable principles explaining relationships between variables, and

- evaluators design their studies to yield data concerning the worth, merit, or values of educational phenomena. Researchers, though, design their studies to discover the truth about educational phenomena (Borg \& Gall, 1983, p. 737-738).

Borg \& Gall (1983) pointed out a good evaluation study satisfies four important criteria, including :

1. Utility is informative, timely, and useful to affected persons.

2. Feasibility means that the evaluation design is appropriate to the setting in which the study is to be conducted.

3. Propriety is cost effective, meaning that the rights of persons affected by the evaluation are protected.

4. Accuracy refers to the extent to which an evaluation study has produced valid, reliable, and comprehensive information about the entity being evaluated (Borg \& Gall, 1983, p. 739).

\section{Evaluation of Student Teaching}

Evaluation of the student teaching experience is very important for helping student teachers grow in the teaching profession by indicating their strengths and weaknesses. The evaluation of student teachers during practice helps them improve and become more effective teachers. Evaluation should be consistent with the stated objectives for student teacher development. The evaluation of the student teaching experience involves more than a measurement and a letter grade given upon completion of the practicum. Boykin (1960) described what the evaluation should entail: Evaluation should reflect the implementation of basic principles, rather than merely the appraisal of specific techniques or the measurement of teacher competencies. The 
evaluation of student teaching involves the consideration of certain problems of relationships, acceptance of basic values, interpretations and understandings of behavior, formulation of judgments, and appraisal of knowledge, skills, attitudes, and appreciation not always taken into account in the processes of arriving at a student's grade or mark in regular college course (Boykin, 1960, p. 8).

He also explained the framework in which the evaluation should be conducted. The nature of the competencies to be developed, the dual role of student teacher, and the scope of the duties and responsibilities, which the student teacher is expected to perform, require that careful consideration be given to the value framework within which judgments are made concerning the student teacher, and the realization of goals to be achieved (Boykin, 1960).

Evaluation is a fundamental aspect of student teaching in particular and of the teacher education program in general. In both cases, it contributes to the professional development of future teachers. The purpose of evaluation is to make inclusive checks as to whether or not the planned procedures for learning experiences actually are yielding the desired outcomes. Evaluation is a powerful process in helping to determine how the student teaching experience is being carried out. As a result, such an evaluation is useful in identifying the strengths and weaknesses of the professional program.

The main objective of evaluation is to bring prospective teachers teaching skills and personality into congruence with the effective teacher behaviors detailed in the literature and endorsed by teacher educators. Bennie (1966) indicated that evaluation is comparative and centered on self-evaluation. Evaluation in this sense does not mean an imposed grade; rather, it is a behavior. Bennie stated that "one cannot overcome his shortcomings unless he first recognizes that they exist" (Bennie, 1967, p .89).

Stratemeyer and Lindsey (1958) suggested that the basic principles of evaluation are:

1. to promote growth,

2. to consider agreed-upon values and goals,

3. to ensure continued progress, 
4. to use both qualitative and quantitative indicators,

5. to be a cooperative process including the student teacher, and

6. to take into account the ability of the learner and the requirements of the situation.

According to Bennie (1972), the basic principles of evaluation are as follows:

- evaluation is comprehensive, including actual classroom activities and other peripheral factors that constitute the whole teaching role.

- evaluation is continuous; "skill in teaching is a gradual growth which the student teacher experiences. His growth is positive and more rapid if he is given evaluative help along the way, enabling him to build on past success and to eliminate or correct weaknesses" (p.104).

- evaluation is specific; generalized suggestions or comments are not of benefit to student teachers who want to learn how to teach and perceive that their teaching endeavors can be improved. Constructive suggestions should be provided, pinpointing both positive and negative aspects of the student's teaching.

- evaluation is individualized; each student teacher is different from his counterparts, and situations are different, as well. "One must base his evaluative approach on not categorizing all student teachers into the same mold or from comparing student teachers with one another" (p. 106).

Fant, Hill, Lee, and Landes (1985) found that $85 \%$ of the teacher training institutions in their study evaluated their student teachers on clarity (clear and straightforward presentation of teaching material), task behavior, use of feedback, task oriented climate, warm and supportive environment, flexibility, adaptability as a teacher, enthusiasm, and high expectations concerning pupils' abilities. The researchers concluded that evaluation of students needs to be done frequently and on a regular basis, established on behavioral terms and based on symbolic indicators that affect the pupils' learning. Student teachers should be informed about the characteristics of effective teachers and expect to be evaluated on those qualities. 
Kong (1978) found the evaluation aspects receiving the highest percentage of responses in terms of practice were evaluation of student teaching that was done by a supervisor. To a great extent, an evaluation of teaching competence was based on growth in the student teacher's ability to use sound educational principles. Evaluation of the student teacher was based on his/her growth and potential in those areas deemed essential for effective teaching. The aspects rated lowest in terms of practice were: evaluation was done by field personnel (supervising teachers and school principals) and reporting the evaluation to the student teachers in anecdotal records.

In Alleyne's (1987) study, the evaluation facets that received the highest ratings in terms of practice were: (a) evaluation of motivated student teachers to improve his/her performance, and (b) evaluation to help the trainee to be aware of his/her strengths and weaknesses. The aspects of evaluation rated lowest with regard to extent of practice were: (a) school principal had input in evaluation of student teachers, (b) the cooperating teachers and college supervisor jointly evaluated the trainee, and (c) final evaluation showed evidence of the student teacher's growth. Student teachers rated the following aspects of evaluation as most important: (a) evaluation motivated me to improve my performance, and (b) evaluation helped me to be cognizant of my shortcomings and strengths. The least important facet of evaluation was the role the school principal played in evaluating the student teacher (Algamdi, 1982).

Edmonds (1985) reported that most evaluation of student teachers in his investigation was done by supervising teachers and college supervisors. Self examination was minimal. Prospective teachers said the college supervisor should have less responsibility in the evaluation. The three most important criteria for evaluation as perceived by future teachers were: (1) a relationship with pupils, (2) the ability to arouse and sustain interest, and (3) energy and enthusiasm.

According to Edmonds (1985), the advantage prospective teachers gain from student teaching include maturity of outlook, exercise of responsibility, increased self-confidence, and skills in human relationship. The relevance of academic studies is thereby enhanced and 
reinforced when theory evolves into practice. The sudden transition of first-year teachers from college to schools without adequate experience in working with school age children and in relating course content to the actual setting or the real world of children can lead to unsuccessful learning experiences from the children and frustration for the novice teacher.

Bennie (1966) distinguished between practice teaching and student teaching. In the latter, the prospective teacher is engaged in a learning situation - a student of teaching. The student teacher is encouraged to learn how to "synthesize the theory he had studied with the experience of teaching into a more complete understanding of teaching and learning" (p.2). Also, according to Bennie (1967), during student teaching (1) the student teacher should become familiar with the total role of the teacher in and out of the classroom, (2) the student teacher should learn how to select, organize, and present classroom work in a variety of ways, (3) the student teacher should learn how to collect, interpret, and use data in the evaluation of pupil and group growth, and (4) the student teacher should develop self-confidence to the point where he can do a credible job of teaching (p. 15).

Student teaching allows pre-service teachers to interact with children and to learn from the different situations they encounter. Not everything taught in college classes is applicable to real life. Thus, student teachers need to learn from the actual setting. As Feiman-Nemser \& Buchmann (1987) stated, "prospective teachers are in a position to start learning from teaching, under guidance, and to see that some of the knowledge they need is 'local.' It can only come through interaction with particular students over time" (p. 256).

According to research by Gallemore (1979), there are 350 objectives of student teaching, which she grouped in three major categories:

1. instruction,

2. class management, and

3. personal and professional growth.

The instruction categories included the following objectives: planning lessons, being able to communicate orally and in writing, applying theory to practice, adapting instruction to meet 
individual needs, demonstrating competence in the specialized area, being resourceful and creative, and using appropriate techniques to evaluate pupil progress. In the class management category were the following specific objectives: effectively handling the daily classroom routine, dealing effectively with pupils, creating a good learning environment, and responding to unpredictable events occurring in the classroom in a wise and sensitive manner. The personal and professional growth category included these objectives: self-evaluation, self-direction, professional growth, self-confidence, interpersonal relations, and an enjoyable personality.

In a study at Cyril Potter College of Education in Guyana, Alleyne (1987) surveyed student teachers after they had completed their student teaching with regard to student teaching objectives. The findings revealed that, in terms of extent of practice, applying theory to practice ranked first, followed by developing self-confidence and developing the professional outlook of the successful teacher. The objective perceived least important during their student teaching was participating in a variety of school and extracurricular activities. Applying theory to practice, developing self-confidence, and developing a professional outlook were perceived as the most important objectives of student teaching. Participating in a variety of school and extracurricular activities was seen as the least important objective.

\section{Summary}

The purpose of this chapter was to give the reader general information about teacher preparation programs, teacher education, and objectives of teacher colleges in Saudi Arabia. This chapter provided the reader information about evaluation in education, evaluation of student teaching, and the importance and objectives of student teaching. Emphasis was given to the teacher preparation and teacher education in Saudi Arabia. 


\section{Chapter 3}

Methodology

This chapter presents the methodology used in collecting information to achieve the objectives of the study and thereby address the research questions. The instrumentation and procedure used in the construction and translation of the instruments are described. In addition, the procedure used to collect the data and the statistical analysis is discussed. Finally, the subject of the study, research questions, population, survey instrument, methods of distributing the questionnaire, translation of the instrument, data collection, and interview procedures are described.

Purpose of the Study

The primary purpose of this study was to analyze teachers' perceptions of the effectiveness of the Social Studies Student Teacher Training Program (SSSTTP) at Tabouk Teachers' College. This is a very important field for study as considerable attention has been given, since early 1989 , to the student teacher training program. Suggestion and additions have been made occasionally on oral or written suggestions from the college supervisors, the deans, the program directors, or the school principal. As previously cited, the student teaching experience is the most important single experience in any teacher education program. This is accurate if these experiences are firm, profitable, and well planned. The continuous and comprehensive analysis of the teacher training program will keep student teaching experiences effective.

Educators have pointed out that the primary purpose of analyzing an educational or training program is to provide information for decisions about the program. This led to the conclusion that well planned analysis is a prudent procedure for improving the Social Studies Student Teacher Training Program at Tabouks' College. 


\section{Research Questions}

The following research questions were posed to investigate the purpose of this study:

1. To what extent do teachers believe that the social studies program and courses taught at Tabouk Teachers' College prepared them for teaching social studies within the principles of Islam?

2. To what extent do teachers feel that the social studies program and courses taught at Tabouks' College prepares them for teaching in Saudi Arabia schools?

3. To what extent do teachers feel that the curriculum meets the needs of the Saudi society?

4. To what extent do teachers feel that the level of technology used at Tabouk Teachers' College prepares them to use technology in teaching?

5. To what extent does the social studies program as taught at Tabouk Teachers' College prepare teachers to use various classroom management techniques in their teaching?

6. To what extent are social studies graduates satisfied with their internship?

\section{Population and Sample for this Study}

Airasian (2003) points out that "sampling is the process of selecting a number of participants for a study in such a way that they represent the larger group from which they were selected. A sample comprises the individuals, items, or events selected from a larger group referred to as a population" (Airasian (2003 p. 101). The sample of 60 male social studies teachers was selected from 33 schools in Tabouk City. Most schools have three or more social studies teachers, but no more than two were selected from any one school. The selected sample showed that the first social studies teacher graduated in academic year 1993. From then until the academic year 2005, 430 teachers have graduated.

Tabouk Teachers' College offers the bachelor's degree. Most of the college supervisors hold the master's degree from different universities, and most principals of the cooperating schools graduated from Tabouk Teachers' College. The researcher contacted the General Directorate of Education in the northwest region in order to secure the names and addresses of 
schools where graduates teach, as well as the names of principals and supervisors from elementary schools for which the colleges has service responsibilities. These were provided.

\section{Survey Instrument: Design and Development}

According to Fink and Kosecoff (1998), a survey "is a method of collecting information directly from people about their ideas, feelings, health, plans, beliefs, and social, educational, and financial background (p. 1). A questionnaire provides the advantage of obtaining responses regarding perceptions of the strengths and weaknesses of the program that usually cannot be obtained through other methods, also, a college survey is designed to obtain student feedback on the institution's impact on student's affective and cognitive development in order to improve student development and document outcomes for accreditation and other external requirements. (Nichols, 1995) The instrument for this study was developed based on information from different sources. Some of the sources include the following elements:

- $\quad$ The information on designing surveys such as Salant \& Diliman (1994), and Fink (1995).

- An extensive review of related literature in teacher preparation such as Hittleman \& Simon (2002).

- Telephone conversations with many graduates to obtain information about the program.

- Related dissertations dealing with program evaluation, such as Hothali (1985), Aseeri (1980), and Alghamdi (1982).

The original questionnaire had a total of 39 items (see Table 5) 
Table 5. Relation between Research Questions and Items

\begin{tabular}{|c|c|}
\hline Number of Question & Items cover the question \\
\hline 1 & 26,38 \\
\hline 2 & $\begin{array}{l}13,14,15,16,17,18,19,22 \\
27,28,29,30,31\end{array}$ \\
\hline 3 & $23,25,26$ \\
\hline 4 & 10,15 \\
\hline 5 & $32,33,34,35,36,37$ \\
\hline 6 & $6,7,8,9,11,12$ \\
\hline
\end{tabular}

A total of 37 were structured response, and three were open-ended questions, and included the following elements:

1. cover letter,

2. demographic information,

3. questions on course work, internship, course instruction, curriculum, and teaching skills, and

4. open-ended questions related to strengths and weaknesses of the social studies program.

Airasian (2003) points out that, "A Likert-type scale asks participants to respond to a series of statements by indicating whether they strongly agree $(\mathrm{SA})$, agree $(\mathrm{A})$, are undecided $(U)$, 
disagree (D), or strongly disagree (SD). Each response is associated with a point value, and an individual's score is determined by summing the point values of each statement. The following point values are typically assigned to positive statements: $S A=5, A=4, U=3, D=2, S D=1$.

According to Salant and Diliman (1994), there are certain recommendations that researchers point to, such as considering using methods that have worked in other surveys on a similar topic. Fink and Kosecoff (1998) state "some people use as many as nine points and others as a few as three (two is yes or no)." They indicate that a small number of choices like four forces the respondents away from the middle ground (neither agree nor disagree). But the needs of the survey and skills of the respondent must, in the end, determine the number of categories. If very precise information is needed, and the respondents are willing and able to give it, use many categories, otherwise fewer categories are recommended (Fink \& Kosecoff, 1998, p. 22). The instruments were also designed to offer usable responses and were administered by the researcher.

\section{Translation of the Instrument to Arabic}

Because the native language of the participants was Arabic, the questionnaire was translated from English into Arabic. The researcher followed a number of steps to guarantee that the translation was correct. The researcher prepared the initial translation. Then, he gave copies of two versions of the questionnaire (English and Arabic) to three Ph.D. students majoring in linguistic studies at the University Kansas, the University of Georgia, and Georgetown University. Three professors in Tabouk Teachers' College in Saudi Arabia who graduated in curriculum and instruction from universities in America and the United Kingdom were provided with the two versions as well. They were asked to examine the translation and make suggestions for changes. Suggestions on which a majority of the reviewers agreed were incorporated into the final survey instrument.

According to Borg and Gall (1983), a questionnaire should be introduced to teachers to make comments to locate any ambiguity. Hence, teachers in the area of specialization (social studies) and the school level (elementary schools), for a total of 15 teachers, were asked to note 
their comments and suggestions regarding the clarity and meaning of the questionnaire. Those subjects gave slight changes, which were carefully considered by the researcher. After this step, the final copy of the questionnaire was ready to be administered in the pilot study of the proposed study.

Pilot Study

A pilot study was conducted with social studies teachers who graduated from Tabouk Teachers' College to establish validity and reliability of the instrument. The Arabic version of the instrument was used and a random group was selected from those who have graduated from Tabouk Teachers' College majoring in the social studies program. The researcher obtained lists of social studies graduates and their postings in schools in the Tabouk area from the Education Department in Tabouk City. Sixteen schools were selected in Tabouk City, and two social studies teachers from nearly four in each school were selected to participate in the pilot study. Thirty-two randomly selected teachers were asked to make changes and suggestions. All selected pilot groups represented social studies graduates who came from different schools at Tabouk City. The original instrument was modified to 40 items (five demographic, seven internship, seven instructor effectiveness, eight curriculum, four teaching skills, six classroom management, and three open-ended questions) that were developed in English and then translated into an Arabic version for distribution to Tabouk Teachers' College, Saudi Arabia.

The instrument was given to 66 graduates in 33 schools in the environs of Tabouk Teachers' College. Care was taken not to select more than two social studies teachers from any one school. Attempts were also made to identify recent and older social studies graduates in this sample. Schools were randomly selected from the Tabouk City area, and teachers were asked to fill out the survey.

Validity

According to Peter Airasian (2003), validity is concerned with the appropriateness of the interpretations made from test scores. Content validity is the degree to which a test measures an intended content area. Concurrent validity is the degree to which scores on one test correlate to 
scores on another test when both tests are administered in the same time frame. Predictive validity is the degree to which a test can predict how well individuals will do in a future situation. Construct validity is the most important form of validity because it asks the fundamental validity question.

One is, therefore, concerned that the items in the instrument really measure the perceptions of social studies teachers in terms of their internship, instructor's effectiveness, curriculum, teacher skills, and classroom management. Deductions can thus be potentially made from the observed scores on the Likert-type scale to a larger population of social studies teachers. To guarantee its validity, the draft instrument was examined and revised by four men who are experts in the area of social studies, including three administrators who have worked in the Ministry of Education for 15 years, one faculty member who works in Umm Alkuraa University, Saudi Arabia, and one who works in the Curriculum Department at Tabouk Teachers' College. The original instrument and the revised instrument. after changes were made based on the experts comments and feedback, are included (see Appendices 1).

Validation was also done by selected professionals from:

1. One person in the Department of Educational Measurement and Research at West Virginia University.

2. One person in the Department of Elementary Education at West Virginia University.

3. The questionnaire was given to the major professor of the committee for his examination and for comments.

4. Four people in Department of Social Studies at Tabouk Teachers' College in Saudi Arabia.

5. Twenty-five graduates of social studies programs at Tabouk Teachers' College. Reliability

According to Airasian (2003), "Reliability is the degree to which a test consistently measures whatever it is measuring." The reliability coefficient may be defined as the percentage of the variance in an observed variable that is accounted for by the true scores on an underlying 
construct (Hatcher \& Stepanski, 1997). In practice, it is a measure of the consistency of the scores that are obtained on the observed variable. An instrument can thus be said to be reliable if it is shown to provide consistent scores if the survey is repeated on the same population. There are several methods of estimating reliability. Among the most commonly used are test-retest and internal consistency reliability. Because the former requires that the instrument be administered more than once, time and cost become important factors. Internal consistency reliability is, therefore, the more widely used index. It provides the lowest estimate of reliability that can be expected for a given instrument, and if other factors are held constant, coefficient alpha will be high to the extent that the scale has many items, and that those items are correlated with each other.

Nunnally (1978) suggests a reliability coefficient of at least .70 but social science literature often reports studies employing variables with reliabilities under 0.60 . The Cronbach alpha coefficient was computed to examine the internal consistency for each scale. This instrument exceeds the standards called for in the social studies literature in that all reliabilities exceed 0.70 . Procedures of Data Collection

To obtain the desired information for this study, the following procedures were followed. The researcher mailed the surveys to Tabouk Teachers' College in Saudi Arabia after receiving approval of his proposal by his doctoral committee and the University Institutional Review Board for the Protection of Human Subjects. Before distributing the questionnaire, the researcher obtained permission from the branch of the Ministry of Education for the Tabouk Region. The surveys were delivered by hand to the participating schools.

All participants were asked to complete an informed consent form before completing the questionnaire, and they were assured anonymity and confidentiality. The participants were asked to return the completed questionnaire to a faculty member at Tabouk Teachers' College. The completed questionnaires were mailed to the researcher. 
Data Analysis

All returned questionnaires were reviewed and analyzed using descriptive and inferential statistics. The quantitative questionnaire data were analyzed using descriptive statistics consisting of means, frequencies, and percentages. For the three qualitative questions, data coding and data analysis were performed manually using an iterative, interpretive approach. 
Chapter 4

Results

In order to obtain answers to the research questions posed for this study, this chapter presents a descriptive statistical analysis of data collected from the questionnaire. The following research questions were posed to investigate the purpose of this study:

1. To what extent do teachers believe that the social studies program and courses taught at Tabouk Teachers' College prepared them for teaching social studies within the principles of Islam?

2. To what extent do teachers feel that the social studies program and courses taught at Tabouk Teachers' College prepares them for teaching in Saudi Arabia schools?

3. To what extent do teachers feel that the curriculum meets the needs of the Saudi society?

4. To what extent do teachers feel that the level of technology used at Tabouk Teachers' College prepares them to use technology in teaching?

5. To what extent does the social studies program as taught at Tabouk Teachers' College prepare teachers to use various classroom management techniques in their teaching?

6. To what extent are social studies graduates satisfied with their internship? 
The questionnaire developed for this study consists of three sections: the first section relates to participants' demographic and background information. The second section investigates participants' perspectives in the following categories:

1. Student Teaching Internship

2. Instructor Effectiveness

3. Curriculum

4. Teaching Skills

\section{Classroom Management}

Items in the second section of the questionnaire employ a five-point Likert-type scale. The third section consisted of three open-ended questions.

Analysis of Demographic Information

The first section of the questionnaire requested demographic information, such as academic degree of teachers, age of teachers, years of teaching experience, grade point average on graduation, and distance lived from the college.

Academic Degree of Teachers

All of the social studies teachers who participated in this study are Saudi nationals. Table 6 shows that most of the teachers $(89.39 \%)$ hold the bachelor's degree in education. About 9.09 percent of the teachers in this study hold the associate degree. Less than $2 \%$ of the teachers in this study hold the teacher certificate. Therefore, almost 90 percent of the teachers have the necessary degree qualifications to teach.

Table 6. Academic Degree of Teachers

\begin{tabular}{|l|l|l|}
\hline I have the following academic qualifications: & Frq. & Perc. $\%$ \\
\hline Teacher Certificate & 1 & $1.52 \%$ \\
\hline Bachelor's degree & 59 & $89.39 \%$ \\
\hline Associate degree & 6 & $9.09 \%$ \\
\hline None & 0 & $0.00 \%$ \\
\hline
\end{tabular}


Age of Teacher

Table 7. Age of Teacher

\begin{tabular}{|l|l|l|}
\hline How old are you? & Frq. & $\begin{array}{l}\text { Perc. } \\
\%\end{array}$ \\
\hline $20-29$ & 28 & $42.42 \%$ \\
\hline $30-39$ & 30 & $45.45 \%$ \\
\hline $40-49$ & 5 & $7.58 \%$ \\
\hline $50-59$ & 2 & $3.03 \%$ \\
\hline $60+$ & 0 & $0.00 \%$ \\
\hline None & 1 & $1.52 \%$ \\
\hline
\end{tabular}

Table 7 shows that most teachers were between 30 and 39 years of age (45.45\%) and (42.42\%) were between 20 and 29 years of age. Combined, these percentages reveal that 87.87 $\%$ of the teachers in the sample were under 39 years of age and representative of a young teaching force. Only two teachers (3.03\%) were between the ages of 50 and 59 . The young age of the teachers might possibly be explained by the fact that these teachers are graduates of Tabouk Teachers' College, and this college has been established for only 18 years.

Table 8. Number of Years' Teaching Experience

\begin{tabular}{|l|l|l|}
\hline How many years have you been teaching? & Frq. & $\begin{array}{l}\text { Perc. } \\
\%\end{array}$ \\
\hline $1-4$ & 18 & $27.27 \%$ \\
\hline $5-9$ & 24 & $36.36 \%$ \\
\hline $10-14$ & 9 & $13.64 \%$ \\
\hline $15-19$ & 9 & $13.64 \%$ \\
\hline $20+$ & 6 & $9.09 \%$ \\
\hline
\end{tabular}

The number of years of teaching experience is displayed in Table 8. Over a quarter of the teachers $(27.27 \%)$ have been teaching from one to four years and $36.36 \%$ have from five to nine years of teaching experience. Nine teachers (13.64\%) report having 10-14 years of experience and nine teachers (13.64\%) report having 15 to 19 years of teaching experience. Six teachers $(9.09 \%)$ report having more that 20 years of experience. The years of experience distribution reveals that $63.63 \%$ of the teachers in this study had nine or less years of teaching. 
Table 9. GPA on Graduation

\begin{tabular}{|l|l|l|}
\hline What was your GPA on graduation? & Frq. & $\begin{array}{l}\text { Perc. } \\
\%\end{array}$ \\
\hline less than 2.0 & 3 & $4.55 \%$ \\
\hline $2.0-2.9$ & 28 & $42.42 \%$ \\
\hline $3.0-3.9$ & 28 & $42.42 \%$ \\
\hline 4.0 & 7 & $10.61 \%$ \\
\hline
\end{tabular}

Table 9 shows the grade point average upon graduation as reported by the teachers in this study. Twenty-eight teachers (42.42\%) report grade point average upon graduation as being between 2.0 and 2.9 and 28 report grade point average as being between 3.0 and 3.9. Therefore, $84.84 \%$ of the teachers had grade point averages between 2.0 and 3.9. Seven teachers (10.61\%) report grade point averages of 4.0 .

Table 10. Distance from College

\begin{tabular}{|l|l|l|}
\hline $\begin{array}{l}\text { My home is/was ..... kilometers away from the } \\
\text { teaching college }\end{array}$ & Frq. & $\begin{array}{l}\text { Perc. } \\
\%\end{array}$ \\
\hline $1-5$ & 15 & $22.73 \%$ \\
\hline $6-10$ & 19 & $28.79 \%$ \\
\hline $11-15$ & 16 & $24.24 \%$ \\
\hline $16-20$ & 11 & $16.67 \%$ \\
\hline more than 30 & 5 & $7.58 \%$ \\
\hline
\end{tabular}

Table 10 shows that $22.73 \%$ of the teachers lived within one to five kilometers from Tabouk Teachers' College. Nineteen teachers (28.79\%) lived from six to 10 kilometers from the college, 24.24 percent from $11-15$ kilometers, $16.67 \% 16$ to 20 kilometers, and $7.58 \%$ more that 30 kilometers. The totals reported indicate that all teachers came from Tabouk City or the Tabouk suburban area.

Student Teaching Internship

Table 11 presents frequencies, percentages, and means of the teachers' responses to items related to the internship (items 6-12 of the questionnaire). Responses were made on a five-point scale ranging from strongly disagreed to strongly agreed. 
It can be seen in Table 11 that 46 teachers (69.70\%) agreed or strongly agreed that the course internship was long enough. Forty-eight teachers (72.73\%) either agreed or strongly agreed that "Adequate teacher support was provided in the internship." In response to item eight, "Adequate teacher feed back was provided in the internship," 46 teachers (69.70\%) responded as either agreed or strongly agreed. Thirty-nine teachers (59.09\%) either agreed or strongly agreed that "I had adequate opportunity to practice my teaching skills." In response to this same item (9) $40.91 \%$ rated the item as neither agreed or disagreed to strongly disagreed. In response to "Adequate technology was provided in my teaching practice," $43.94 \%$ either agreed or strongly agreed, with $56.06 \%$ either neutral to strongly disagreed. Interestingly, $28.79 \%$ either disagreed or strongly disagreed in response to item 10 . Forty-three teachers (65.15\%) either agreed or strongly agreed that "My internship linked classroom practice and theory." Twenty-three teachers (34.85\%) were either neutral or disagreed with item number 11 . Fifty-three teachers $(80.30 \%)$ either agreed or strongly agreed that "Good relationships exist between student teachers and cooperating school personnel." Only $4.55 \%$ either disagreed or strongly disagreed with this statement.

Table 12 presents frequencies, percentages, and means for Instructor Effectiveness. The response for Item 13, "Had expert knowledge in their field," showed $87.88 \%$ either agreed or strongly agreed with the statement. Therefore, the teachers believed their instructors to possess expert knowledge in their field. The results for "Used a variety of teaching techniques to enhance critical thinking skills" showed that $63.64 \%$ agreed or strongly agreed with this statement, $12.12 \%$ disagreed or strongly disagreed, and $24.24 \%$ neither agreed nor disagreed. In item 15, over onehalf of the teachers (57.58\%) either agreed or strongly agreed that the instructor "Used technology to enhance instruction." Almost one-quarter of the respondents (22.73\%) disagreed that the instructor used technology to enhance instruction. In response to "The instructors were supportive of individual student needs," over one-half (56.06\%) responded that they agreed or strongly agreed with this statement. It is interesting to note that $44.34 \%$ of the responses fell between neither agreed nor disagreed and strongly disagreed. Over one-half (57.58\%) felt that 
the instructors "Maintained student interest in the courses by using real-life applications." Thirtythree percent indicated that they neither agreed nor disagreed with this statement. A little over half $(56.06 \%)$ indicated that they agreed or strongly agreed that the instructor "Always found the time to help students." Therefore, $43.94 \%$ were either neutral or disagreed with this statement. In relation to item $19,54.55 \%$ either agreed or strongly agreed that the instructor "Provided adequate opportunities for feedback on my performance." Over one-fourth of the responses fell in the neither agreed nor disagreed column. There were $18.19 \%$ who either disagreed or strongly disagreed with this statement.

\section{Curriculum}

Table 13 presents the frequencies, percentages, and means for Curriculum. Less than half of the teachers (43.94\%) agreed or strongly agreed that the curriculum "Had input from both administrators and teachers." Over $30 \%$ disagreed or strongly disagreed $(31.82 \%)$ that administrators and teachers had input into the curriculum. The response to Item $21,63.63 \%$ either agreed or strongly agreed that the curriculum "Was well designed," with 15.16\% disagreed with this statement. Over three-fourths (75.76\%) agreed or strongly agreed that the curriculum "Has helped me in my classroom teaching." Only $7.58 \%$ indicated that they disagreed with this statement. Item 23 asks if "The curriculum is relevant to the needs of Saudi society." An overwhelming majority (80.30\%) indicated that they agreed or strongly agreed with this statement. In response to Item $24,69.70 \%$ either agreed or strongly agreed that the curriculum "Should be completely revised." The remaining responses show that 12.13 either disagreed or strongly disagreed and $18.18 \%$ neither agreed nor disagreed. For Item 25 , over half of the teachers $(54.54 \%)$ felt that the curriculum "Was relevant to prospective teachers," while $31.82 \%$ neither agreed nor disagree. Over three-fourths (77.27\%) of those responding to Item 26 indicated that the curriculum "Was relevant to Saudi society." For Item 27, 69.70\% either agreed or strongly agreed that the curriculum "Has helped me to master the skills necessary to be a competent classroom teacher." In responding to this same item, $10.61 \%$ either disagreed or strongly disagreed. 


\section{Teaching Skills}

Table 14 presents the frequencies, percentages, and means for the questionnaire items related to Teaching Skills. The responses to the items related to teaching skills clearly show that the overwhelming majority agreed or strongly agreed with each statement. The responses show that $74.24 \%$ either agreed or strongly agreed that they learned "Proactive classroom management techniques" and also learned "To use examples from other disciplines to help my students learn social studies." In relation to Item 29, $77.28 \%$ either agreed or strongly agreed that they learned "Appropriate instructional approaches to promote social studies learning." For item $30,75.76 \%$ indicate that they have learned "To adjust instruction based on assessment of student progress." The percentage of those indicating disagreed or strongly disagreed was under $15 \%$ for the four items.

\section{Classroom Management}

Table 15 presents the frequencies, percentages, and means for the items dealing with classroom management. Overall, the ranking of the items on the five-point scale are quite positive. Item 32 shows that $71.21 \%$ of the teachers either agreed or strongly agreed that they were informed of "Proactive classroom techniques." Only $15.16 \%$ disagreed or strongly disagreed. Forty-seven (71.21\%) of the teachers either agreed or strongly agreed that they were provided with "Ways to control excessive talking in the classroom." Only $18.18 \%$ either disagreed or strongly disagreed. In relation to Item 34 , it can be seen that 46 teachers (69.69\%) either agreed or strongly agreed that the program provided them with "Ways to control aggressive behavior in the classroom." There were eight teachers (12.13\%) who either disagreed or strongly disagreed. Twelve teachers (18.18\%) neither agreed nor disagreed. Fifty teachers $(75.76 \%)$ agreed or strongly agreed that they were told "How to get students to work in successful teams." Six teachers (9.10\%) either disagreed or strongly disagreed and $18.18 \%$ neither disagreed nor disagreed. Fifty-seven teachers (86.37\%) either agreed or strongly agreed that they were provided with information on "How to ensure student participation in lessons." Fifty-four teachers (81.82\%) either agreed or strongly agreed that they were informed on "How to improve social 
competence in the classroom." Only $9.09 \%$ of the teachers either disagreed with the statement in Item 37 or neither agreed nor disagreed with the item.

\section{Open Ended Questions}

Following an iterative, interpretive approach to data analysis, the following themes were identified.

Question 38 asked, "To what degree has your education strengthened your ability to teach social studies within the principle of Islamic religion?" Those responding to this question indicated that their education had strengthened their ability to teach social studies within the principle of Islam. Students responded that the effectiveness of the program was excellent. It should be noted that only four teachers responded to this question.

Question 39 asked the teachers to respond to the strengths of the Social Studies Teacher Preparation Program. There was strong agreement among the respondents that an excellent relationship existed between the students and school personnel. The instructors of the program made the students feel that they were important and worked on establishing good relationships with school personnel. Excellent relationships between students and school personnel do not necessarily imply that the program was effective, but it does imply that the school staff was listening to the student teachers and their concerns. The teachers responded that the professional education courses offered by the program positively strengthened their ability to teach. Many of the 59 respondents viewed the program and its education as excellent. They reported that the experiences provided by the program were valuable and contributed greatly to enhancing one's ability to teach.

Question 40 asked the teachers to respond to any perceived weaknesses of the Social Studies Teacher Preparation Program. Only three teachers responded to this question and no weaknesses were reported. 
Teacher Preparation Effectiveness 58

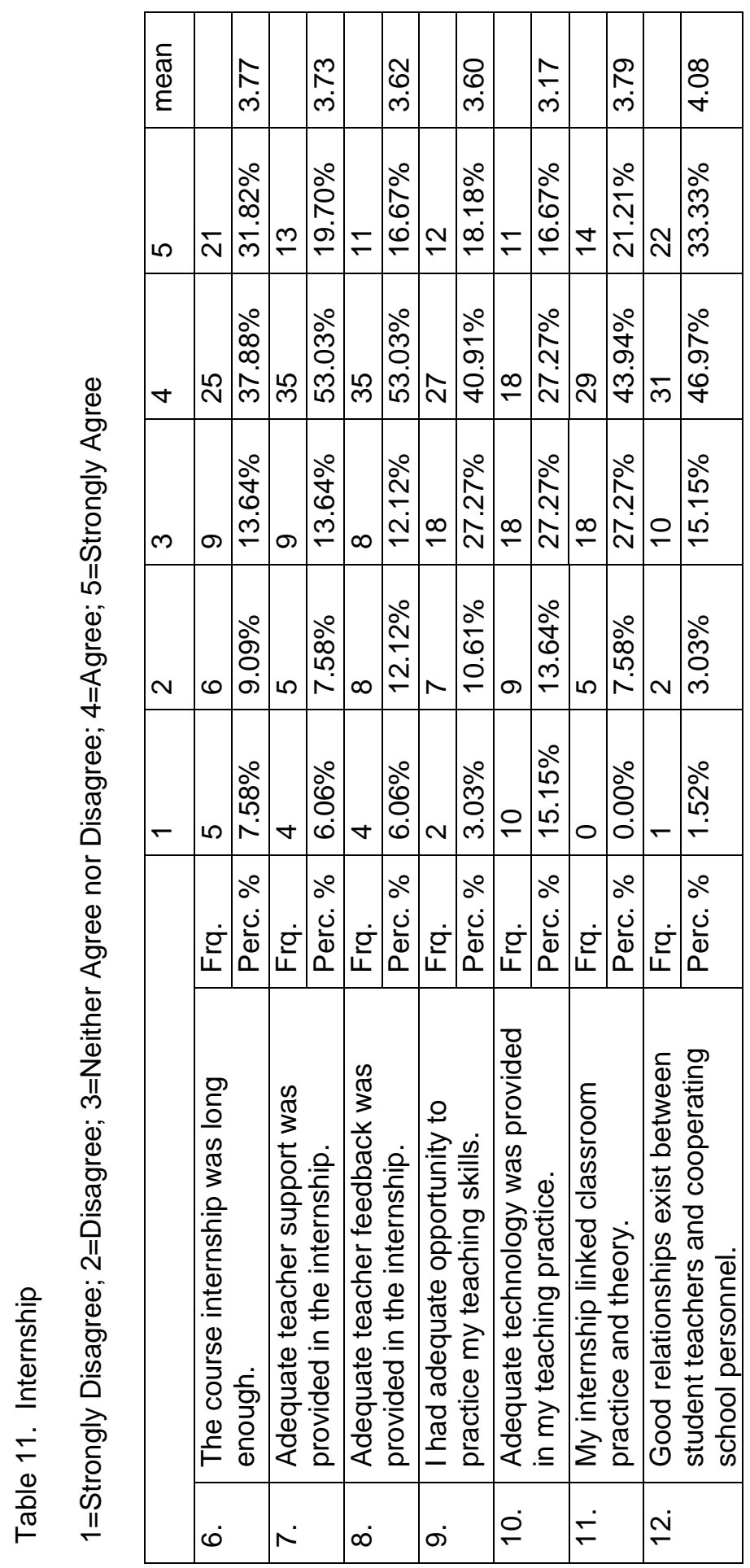


Teacher Preparation Effectiveness 59

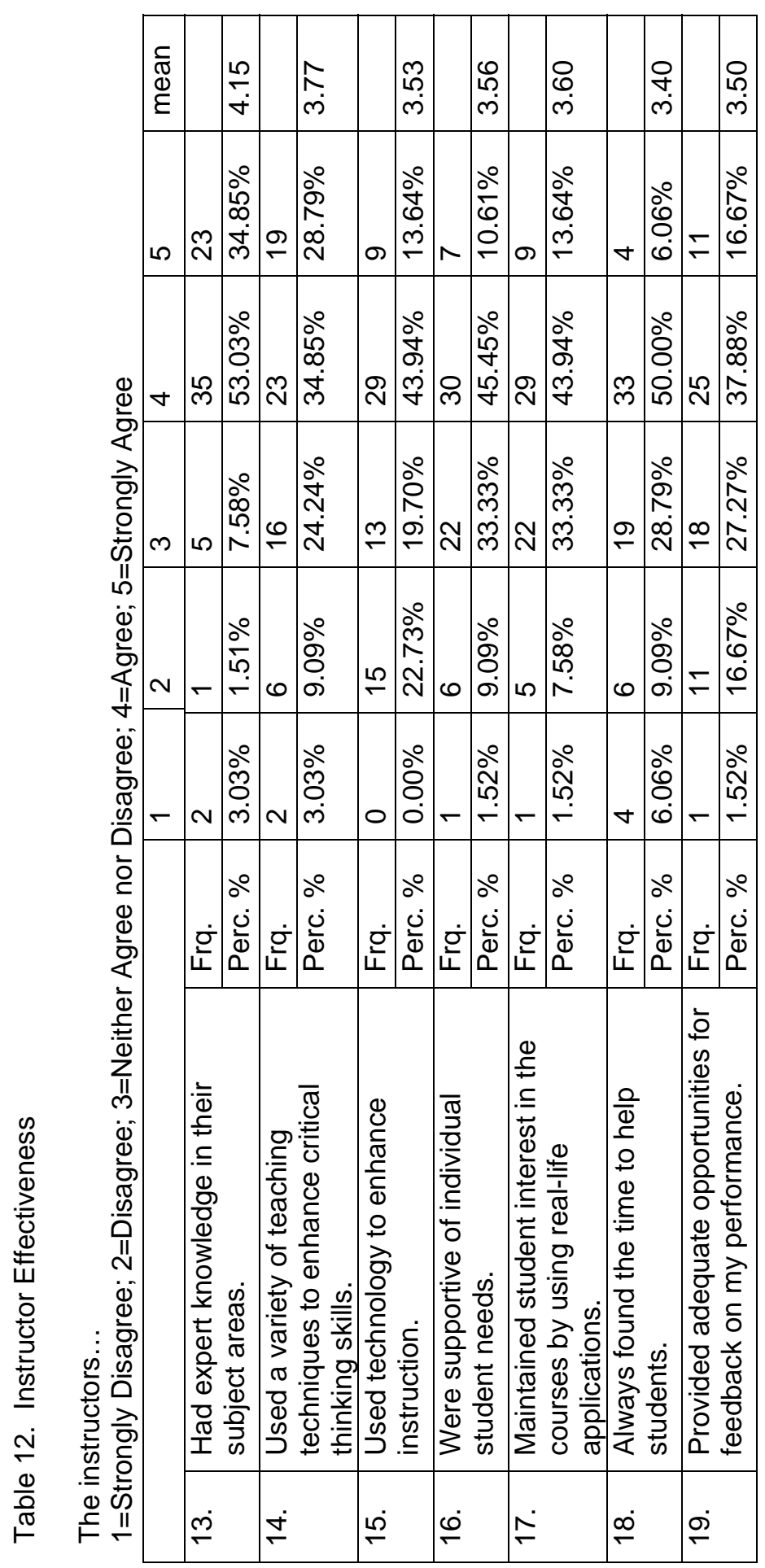




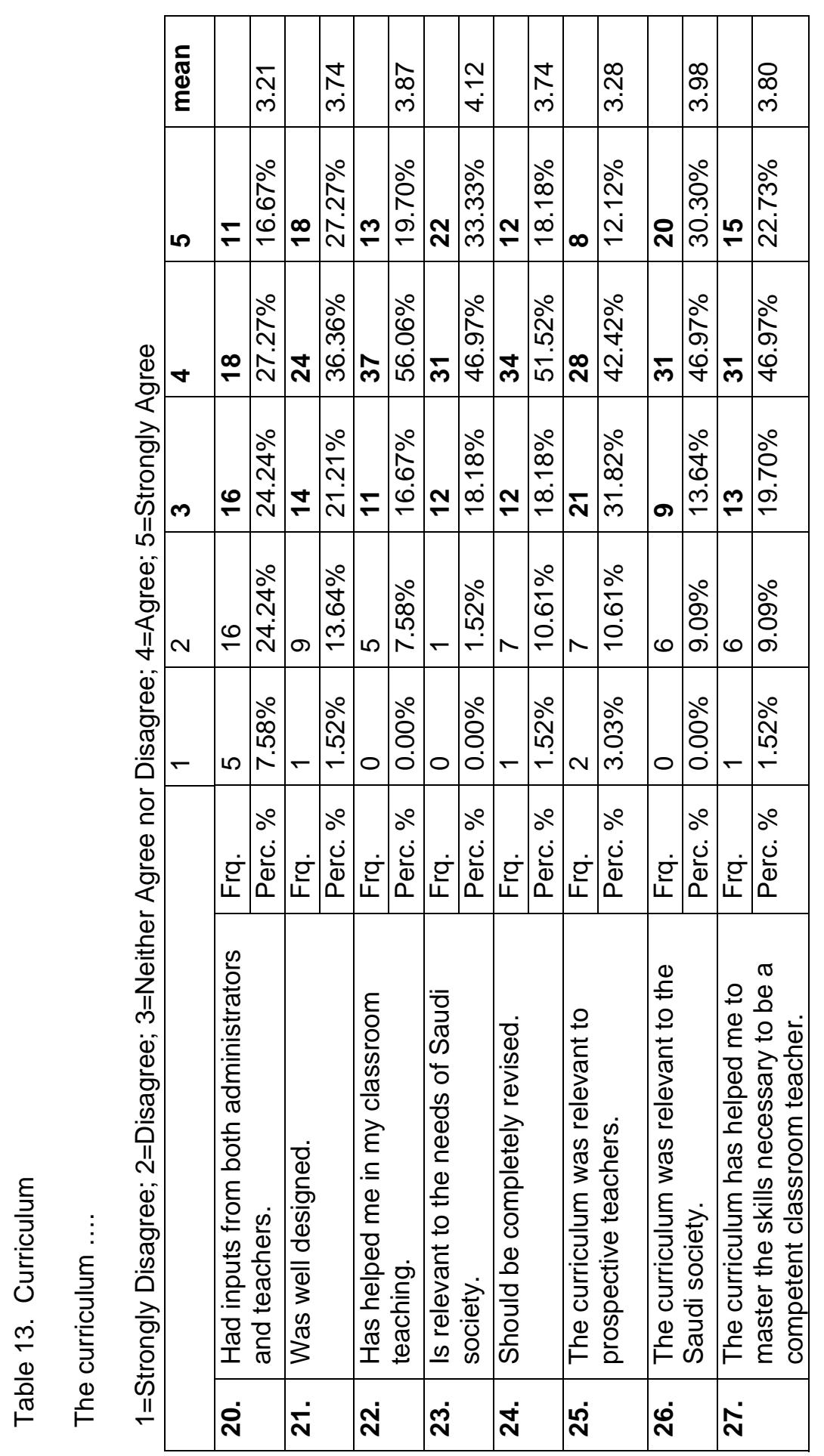


Teacher Preparation Effectiveness 61

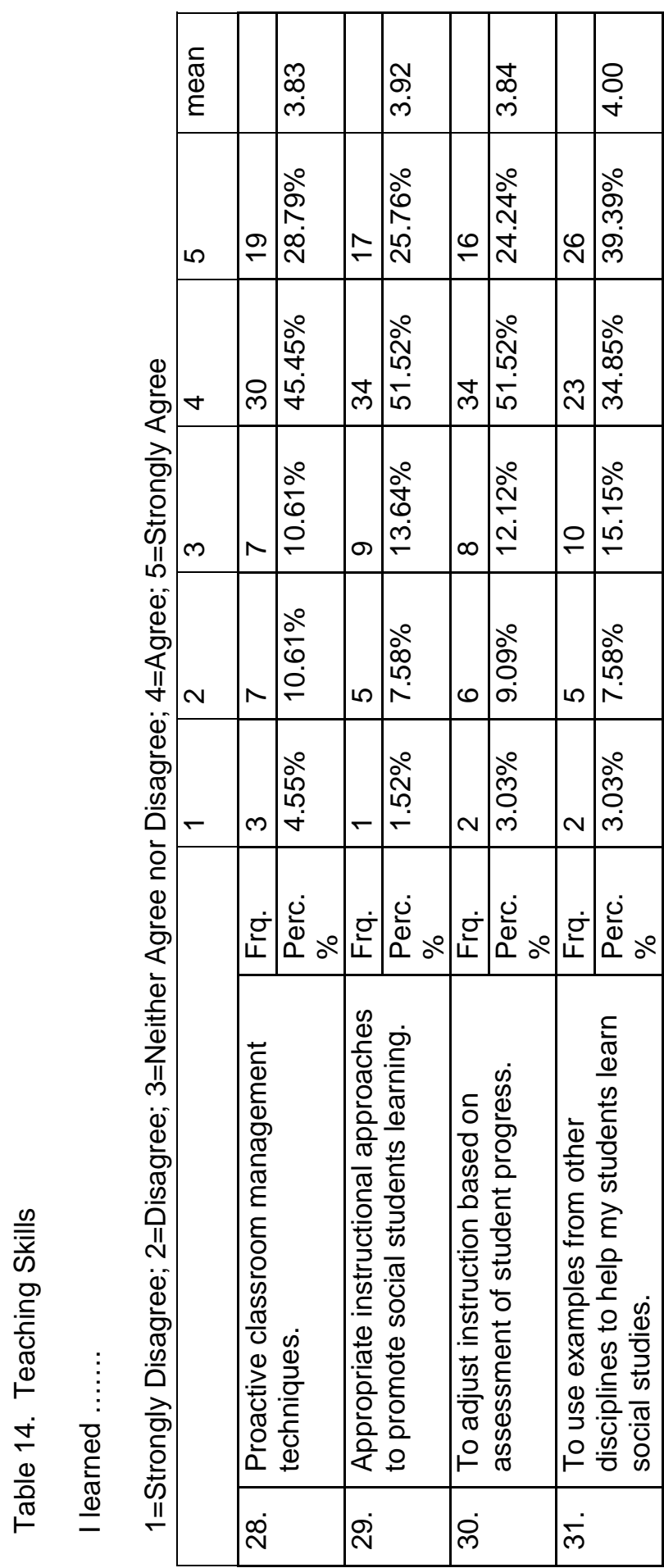


Teacher Preparation Effectiveness 62

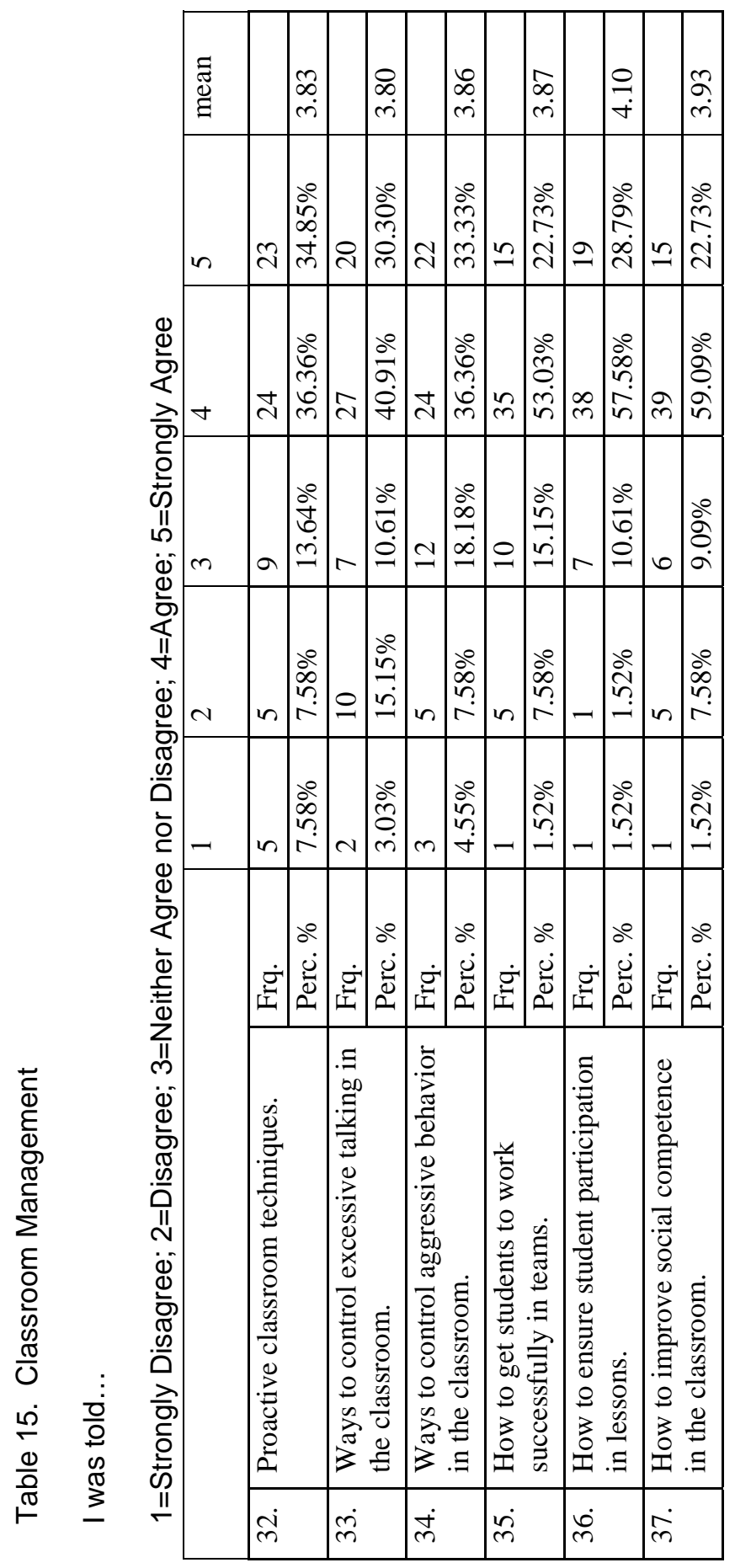


Chapter 5

Summary, Findings, Conclusions, and Recommendations

\section{Summary}

This chapter presents a brief summary of the study including purpose, research questions, summary of the findings, conclusions, and recommendations. Educational leaders in Saudi Arabia are paying careful attention to the quality of education in their nation. Concerns in Saudi Arabia regarding improving the quality of teacher education have led to widespread calls for reform, change, innovation, or improvement in education (Al-Salloom, 1991). These are linked in one way or another to improvement in teacher education. It is through teacher preparation programs that new knowledge, skills, and values could be passed on to the younger generation. This is why when education policy is questioned, teacher education is often blamed for shortcomings in the system. Studies have shown that the quantity and quality of public education may depend both directly and indirectly on the quantity and quality of teacher preparation programs (Goodlad, 1990, Judge, 1990, \& Pearson, 1989).

The main purpose of this study was to analyze teachers' perceptions of the effectiveness of the Social Studies Teacher Training Program at Tabouk Teachers' College in Tabouk City, Saudi Arabia. The researcher strongly believes in the importance of this field of study. Since the establishment of Tabouk Teachers' College, considerable attention has been given to the student teacher training program. While changes and additions have been made from year to year, they were not based on a reliable and comprehensive analysis of this program, but rather on oral or written suggestions from the college supervisors, the deans, the school principals, or the program directors. The student teaching experience is the most important single experience in any teacher education program. This is true if these experiences are strong, beneficial, and well planned. 
This research study was designed to answer the following questions:

1. To what extent do teachers believe that the social studies program and courses taught at Tabouk Teachers' College prepared them for teaching social studies within the principles of Islam?

2. To what extent do teachers feel that the social studies program and courses taught at Tabouk Teachers' College prepares them for teaching in Saudi Arabia schools?

3. To what extent do teachers feel that the curriculum meets the needs of the Saudi society?

4. To what extent do teachers feel that the level of technology used at Tabouk Teachers' College prepares them to use technology in teaching?

5. To what extent does the social studies program as taught at Tabouk Teachers' College prepare teachers to use various classroom management techniques in their teaching?

6. To what extent are social studies graduates satisfied with their internship?

In order to obtain answers to the research questions posed for this study, a questionnaire was used to collect the data for this research study. The questionnaire (Appendix B) consisted of three sections: the first section requested demographic information from the participants including educational qualifications, age, number of year's experience, and grade point average earned in the program. The second section investigated participants' perceptions of the effectiveness of the social studies teacher preparation program in the categories of student teaching internship, instructor effectiveness, curriculum, teaching skills, and classroom management. Items in the second section of the questionnaire employed a five-point Likert-type scale. The third section consisted of three open-ended questions.

The population for this study consisted of teacher education graduates from Tabouk Teachers' College, located in Tabouk City, Saudi Arabia. The school selection was random. Questionnaire data were collected from 66 graduates in 33 schools in the area served by Tabouk Teachers' College. Care was taken not to select more than two social studies teachers from any one school. Attempts were also made to identify recent and older social studies graduates in this sample. The schools were randomly 
selected and were located in Tabouk City. All returned questionnaires were reviewed and analyzed using descriptive and inferential statistics. The quantitative questionnaire data were analyzed using descriptive statistics consisting of means, frequencies, and percentages. For the three qualitative questions, data coding and data analysis were performed manually using the iterative, interpretive approach.

Findings

Information from the demographic section of the questionnaire revealed that all teachers surveyed were Saudi nationals. Among the teachers surveyed, $89.39 \%$ hold a bachelor's degree and $10.61 \%$ hold an associate degree or the teacher certificate. These data indicate that almost $90 \%$ of the respondents were sufficiently credentialed and have the appropriate educational background for their position as social studies teachers. Of the teachers surveyed, $87.87 \%$ were between 20-39 years of age. Only $12.13 \%$ fell outside this age range. The age demographic reveals that the teachers surveyed were relatively young. The high percentage of faculty under the age of 39 can be explained by the fact that those surveyed graduated from Tabouk Teachers' College and the College has been in existence for only 18 years. In terms of years of teaching experience, over half (63.63\%) had nine or less years of teaching experience and $27.28 \%$ had between 10 and 19 years of teaching. The data on grade point average upon graduation from the program revealed that $42.42 \%$ of the sample had between $2.0-2.9$ and $42.42 \%$ between 3.0-3.9. The data show that $10.61 \%$ had a 4.0 grade point average.

Research question one asked, "To what extent do teachers believe that the social studies program and courses taught at Tabouk Teachers' College prepared them for teaching social studies within the principles of Islam?" This data for this question were obtained from items 23, 26, and 38 of the survey. An overwhelming majority (80.30\%) responded that they agreed or strongly agreed that the curriculum was "relevant to the needs of Saudi society." Over three-fourths (77.27\%) indicated that the curriculum was "relevant to Saudi society."

Question 38 asked, "To what degree has your education strengthened your ability to teach social studies within the principle of the Islamic religion?" Those responding to this question indicated that their education had strengthened their ability to teach social studies in accordance with the principles of Islam. 
Respondents indicated that the effectiveness of the program was excellent; however it should be noted that only four teachers responded to this question.

Research question two asked, "To what extent do teachers feel that the instruction provided in the social studies program and courses taught at Tabouk Teachers' College prepared them for teaching in Saudi Arabian schools?" Over three-fourths (87.88\%) responded that their instructors possessed expert knowledge in their subject area. The mean of 4.15 for item 13 was the highest for any item in the questionnaire. It would appear from the data that the teachers surveyed believed their instructors to have expert knowledge in their field. Generally high marks (63.64\%) were given for instructors using a variety of teaching techniques, though nearly one-fourth (24.24\%) were neutral in their response to this item. In terms of instructor use of technology to enhance instruction, the responses were more mixed. About half (57.58\%) rated technology use as a four or five. However, $22.73 \%$ disagreed that technology was used to enhance instruction and $19.70 \%$ neither agreed not disagreed. This data indicates that technology use is an area that can be improved. For items 16 through 19 (see Table 12) the mean ratings fell around 3.50. Though a little over half of the respondents indicated that they agreed or strongly agreed with the statements, over $40 \%$ of the responses fell between neither agreed nor disagreed and strongly disagreed. This is a high percentage of respondents falling between the midpoint and the end of the scale. The two lower rated items, "Always found the time to help students" (mean 3.40) and "Provided adequate opportunities for feedback on my performance" (mean 3.50), appear to be areas in need of further examination.

The responses to the items related to "Teaching Skills" clearly showed that an overwhelming majority of the respondents agreed or strongly agreed with each item. Over $75 \%$ reported that they learned proactive classroom management techniques and appropriate instructional approaches to promote social studies learning. They also reported that they learned to adjust instruction based on assessment of student progress and to use examples from other disciplines to help their students learn social studies. The data clearly reflected that the section on teaching skills represents an area of strength in the program. 
Research question three asked, "To what extent do teachers feel that the curriculum meets the needs of the Saudi society?" The responses for this question were somewhat mixed. Over three-fourths of the respondents either agreed or strongly agreed that the curriculum was relevant to Saudi society. Responses revealed a positive perception of curricular efficacy with respect to later classroom teaching experiences. The data showed a mean of 3.28 for "The curriculum was relevant to prospective teachers." Over 30\% (31.82\%) neither agreed nor disagreed with this item. This rating deserves further exploration. The lowest mean rating (3.21) for curriculum was for the prompt, "The curriculum had input from both administrators and teachers." The total percentage for disagreed or strongly disagreed was $31.82 \%$. Another $24.24 \%$ neither agreed nor disagreed. The data clearly show that curriculum input is an area that needs further examination. The data for curriculum show that $63.63 \%$ of the teachers agreed or strongly agreed that the program was well designed. The respondents also agreed or strongly agreed that the curriculum helped them to master the skills necessary to be a competent classroom teacher. In spite of this strong support for the program, $69.70 \%$ either agreed or strongly agreed that the curriculum should be completely revised. This apparent contradiction in perceptions of the curriculum is an area that needs further examination.

It is recommended that this survey be administered again with a large increase in the number of participants and that factor analysis be used to analyze the responses. This could be done in a collaborative way involving instructors with a background in mathematics.

It is recommended that similar research be done with other teachers. Would teachers of mathematics or science view the program in the same light as the social studies teachers?

Research question four asked, "To what extent do teachers feel that the level of technology used at Tabouk Teachers' College prepares them to use technology in teaching?" This question is addressed by items 10 and 15 of the questionnaire. The responses to item 10, "Adequate technology was provided in my teaching practice," showed a mean rating of 3.17 , where $28.79 \%$ of the respondents either disagreed or strongly disagreed with the statement. Another $27.27 \%$ neither agreed nor disagreed. This data showed that less than half of the respondents felt that adequate technology was provided. The use of technology to enhance instruction was another item where $22.73 \%$ disagreed with the statement. 
Another $19.70 \%$ neither agreed nor disagreed. This represents 28 respondents out of the total 66 . The data suggest that the use of technology in teaching is an area that can be improved. The differences in responses to the technology questions indicated that adequate technology is not used to enhance instruction.

Research question five asked, "To what extent does the social studies program as taught at Tabouk Teachers' College prepare teachers to use various classroom management techniques in their teaching?" The responses to questions related to classroom management were overwhelmingly positive. The percentages for all items ranged from about $70 \%$ to a high of $86 \%$ on how to get students to work successfully in teams. The teachers responded that they were informed of proactive techniques for managing a classroom. The ratings for classroom management revealed that this is an area of strength in the social studies preparation program at Tabouk Teachers' College.

Research question six asked, "To what extent are social studies graduates satisfied with their internship?" The data for the internship show that the vast majority of the respondents were satisfied with their student teaching internship. They were satisfied with the length of the internship, with the level of teacher support for the experience, and with the linking of classroom practice and theory. The data show that the graduates were very pleased with the good relationships that existed between student teachers and cooperating school personnel. About $60 \%$ of the teachers agreed or strongly agreed that there was adequate opportunity to practice their teaching skills. This is an area that warrants further examination. The item related to adequate technology being provided in the teaching practice received the lowest rating (43.94\%). As stated previously, this is an area of apparent weakness in the social studies teacher preparation program.

\section{Limitations and Directions for Further Research}

The primary limitation of this study is the relatively small sample size. While a total of 66 respondents provided a moderate sample size, the fact that they were from a total of 33 schools limits the utility of the findings. Specifically, it is possible that institutional variations may have existed but were masked by a mean of two respondents per institution. As such, the first recommendation of this study is 
future studies should seek to achieve a greater number of total participants as well as a higher rate of participation across institutions.

Alternatively, a large number of responses could be obtained at select institutions and anomalous findings from this study could then be used as a basis for selectively targeting further research. From a research perspective this can be explained as the establishment of normative nested data sets, with outliers serving as the basis for further inquiry.

Aside sample size, there were several instances in which the quantitative data showed a majority of participants expressed a given opinion, yet it was not overwhelming. More research is needed in these areas.

As an example, $60 \%$ of respondents believe they had adequate opportunities to utilize their teaching skills. However, the minority (40\%) constituted a significant population. As such, more inquiry is needed to develop an understanding of what factors led the minority to express this opinion. In fact, for the development of effective curriculum such inquiry is essential.

The second major area for future research is the effective integration of technology. Approximately half of the respondents believed that technology was not significantly integrated into the curriculum of their school. However, this number is strikingly similar to the number of respondents who believed they did not receive adequate preparation in the use of technology. Therefore, one has to question if a causal relationship is at work. Specifically, does the lack of technological training lead to perceptions of inadequate availability of resources?

The anomaly existing in the responses to curriculum might have been due to cultural issues or to how the items were translated.

Finally, an area in which respondents believed that their training was strong was in the area of classroom management; a belief expressed by $75 \%$. From a cultural perspective this is an area that I find quite interesting. Upon reflection, I have to ask if cultural differences alter the way teachers in this study view classroom management issues as compared to teachers in other parts of the world. 
Perhaps this last question is one that should be considered and contextualized in all future research of this population. Specifically, as this study was constructed against the paradigm of western pedagogical effectiveness, one has to wonder if cultural variables should be a part of future research constructs. 


\section{References}

Adeyemi, M. (1982). Preparing secondary school teachers of social studies in Nigeria. The Social Studies, 80(5), 203-204

Adeyemi, M. (1989). Preparing secondary school teachers of social studies in Nigeria. The Social Studies, 80(5), 203-204.

AL Asem, M. (2003). A attitudes of Social Studies Supervisors and Teachers Towards the Teachers' Evaluation System in Saudi Arabia. Unpublished doctoral dissertation, University of Arkansas.

Al-Ahmed, Abdulrahman A. (1979). A study of effectiveness of the teacher preparation program at Kuwait University: Based on a follow-up of 1979 graduates (Doctoral dissertation, Michigan State University, 1978). Dissertation Abstracts International, 40, 801A.

Al-Aklobi, F. A. (1992). A survey of the attitudes of social studies teachers and supervisors toward social studies education in boys secondary schools of the Saudi Eastern province. Unpublished doctoral dissertation, University of Mississippi.

Al-Dail, A. S. (1979). A study to identify ways of increasing the enrollment of Saudi male elementary school teachers in teacher training institutions and improving the quality of instruction in those institutes. Dissertation Abstracts International, 40, 1758A-1759A. (University Microfilms No.79-17,107)

Al-Ghamdi, A. M. (1982). The professional development of in-service teachers in Saudi Arabia: A study of the practice and needs. Dissertation Abstracts International, 43, 423A -2968A. (University Microfilms No. $83-03,745)$

Alghamdi, A. S. (1982). Content evaluation of physical education teacher preparation program at Umm AlQura University in Makkah, Saudi Arabia. Unpublished doctoral dissertation, Michigan State University. Alleyne, C. J. (1987). The student teaching experience at Cyril Potter College of Education, Guyana, as perceived by student teachers. Unpublished doctoral dissertation, Teachers College, Columbia University.

Al-Malki, A. A. (1995). A Dictionary of Religious Terms. Obeikan Bookshop. 
Al-Raway, M. K. (1988). An analysis of competencies needs by secondary school teachers of United Arab Emirates. Unpublished Ed.D. Dissertation, University of Pittsburgh.

Al-Salloom, H. I. (1991). General education in the Kingdom of Saudi Arabia. Washington, D.C.: International Press.

Al-Wabli, S. M. (1982). An evaluation of selected aspects of the secondary teacher preparation program at the Umm Al-Qura University, Makkah, Saudi Arabia, based on a follow-up of 1978-1979 graduates. Dissertation Abstracts International, 43,423A. (University Microfilms No.82-16,516).

Apple, R. L. (1966). An evaluation of the secondary teacher education program at North Park College based upon a follow-up study of the academic record of the secondary teacher graduates. Unpublished doctoral thesis, University of Colorado .

Applegate, J. H. (1986). Undergraduate students' perceptions of field experiences: Toward a framework for study. In Raths, J. D., \& Katz, L. G. (Eds.), Advances in teacher education (Vol. 2). Norwood, NJ: Ablex.

Aseeri, M. S. (1980). Evaluation of social studies student teaching programs in the junior colleges of Taif and Abha—goals, procedures, resources, and program management. Unpublished doctoral dissertation, University of Colorado.

Barr, R., Barth, J., \& Shermis, S. (1978). The nature of the social studies. California: ETC Publication.

Barth, J., \& Shermis, S. (1980). Social studies goals: Development in Education, 13(2), 1-11.

Bennie, W. A. (1966). Cooperation for better student teaching. Minneapolis: Burgess Publishing Company.

Bennie, W. A. (1972). Supervising clinical experiences in the classroom. NEW York: Harper \&Row.

Blom, M. (1988). Citizenship for the 21st century: The role of the social studies. A view from Sweden. Social Education, 52(7), 490-492, 506.

Bode, B. (1940). How we learn. Boston: D. C. Health and Company.

Borg, W., \& Gall, M. D. (1983). Educational research. New York: Longman. 
Boykin, L. (1960). Principles of evaluating student teaching. In Evaluating Student Teaching: A forward look at theories and practices. Thirty-ninth yearbook of the association for student teaching. Dubuque, IA: Wm. C. Brown.

Brown, T. J. (1962). Student teaching in elementary school. New York: Harper \& Row Publishers.

Cogan, J . (1989). Citizenship for the 21st century: observations and reflections. Social Education, 53(4), 243-245.

Conant, J. B. (1964). Teacher certification: The restricted state approved program approach (Bulletin No.22). Cedar Falls, IA: Association for Student Teaching.

Dickenson, W. R. (1980). A follow-up study of attitudes of central Michigan University graduates of the years 1973-1976 toward the undergraduate teacher education program (Doctoral dissertation, Michigan State University, 1979). Dissertation Abstracts International, 40, 6235A.

Dover. W. (1964). The experience of student teaching. New York: The Macmillan Company.

Dueck, K., Altmann, H., Latimer, J. (1984). Early exploratory field experiences in teacher preparation programs. Education Canada, 24(1), 34-38.

Edmonds, E.L. (1985), January-March. Can universities teach student teachers how to teach? Higher education in Europe, 10(1), 94-100.

Etim, J. S. (1980). An analysis of first and second year secondary school teachers' perceptions of their preservice preparation curricula in their universities in Nigeria with implications for future planning and development of the teacher education curricula. (Doctoral dissertation, University of Wyoming, 1979). Dissertation Abstracts International, 41, 1370 A.

Evans, R. (1989a). A dream unrealized: A brief look at studies, 80(5), 178-184.

Fant, H., Hill, C., Lee, A., \& Landes, R. (1985). Evaluating student teachers: The national scene. Teacher education, 21(2), 2-8.

Feiman-Nemser, S., \& Buchmann, M. (1987). When is student teaching teacher education? Teaching and teacher education, 3(4), 255-273.

Fink, A. (1995). The survey handbook, Vol. 9. Thousand Oaks, CA: Sage Publications. 
Fnk, A., \& Kosecoff, J. (1998). How to conduct surveys: A step-by-step guide. Thousand Oaks, CA: Sage Publications, Inc.

Gallemore, S. L. (1979). Student teaching objectives: Their importance and achievement. (ERIC Document Reproduction Service No. ED 218 265).

Goodlad, J. (1979). What schools are for. U.S.: Phi Delta Kappa Educational Foundation.

Goodlad, J. I. (1990). Teachers for our nation's schools. San Francisco: Jossey-Bass Publishers.

Graff, Paul R. (1977). A follow-up study of graduates and their opinion of the secondary teacher education program of the University of lowa, 1970-1916. (Doctoral dissertation, University of lowa, 1976). Dissertation Abstracts International, 37, 7698 A.

Gross, R., Messick, R., Chapin, J., \& Sutherland, J. (1978). Social studies for our time. New York: John Wiley and Sons.

Hamdan, M. Z. (1981). A comparative analysis of the Saudi male elementary teacher preparation program. Unpublished doctoral dissertation, Kent State University.

Hatcher, L., \& Stepanski, E. (1997). SAS System for University and Multivariate Statistics. Cary, NC: SAS Institute, Inc.

Hepburn, M., \& Keach, Jr ., E. (1974). The impact of environmentalism on the social studies curriculum. The Journal of Environmental Education, 5(3), 15-18.

Hertzberg, H. (1981). Social studies reform 1880-1980. Boulder, CO: Social science Education Consortium, Inc. (ERIC Document Reproduction Service No. ED 211429).

Hittleman, D. R., \& Simon, A. J. (2002). Interpreting educational research (3rd Ed). Saddle River, NJ: Upper Saddle River.

Hothali, A. M. (1985). Evaluation of the elementary social studies teacher training programs at Makkah and Taif junior colleges in Saudi Arabia. Unpublished doctoral dissertation, University of Pittsburgh.

Jensen, D. M. (1971). A follow-up study of graduates of the secondary teacher education of the University of lowa 1966-1970. (Doctoral dissertation, University of lowa, 1971) Dissertation Abstracts International, 32, 2531A.

Johany, A. D. (1986). The Saudi Arabia Economy. Baltimore: Johns Hopkins University Press. 
Johnson, J. A., \& Anderson, R. C. (1971). Secondary student teaching: Readings. Glenview, Illinois: Scott, Forsman \& Company.

Judge, H. (1990). The education of teachers in England and Wales. In Gambert, E. B., Fit to teach, Vol. 8. Atlanta, GA: Georgia State University.

Kaywell, J., \& Carroll, R. (1988). Education in the year 2000: Possible and preferable futures. The Clearing House, 62(1), 11-13.

Kong, A. C. (1978). Student teachers' perceptions of their student teaching with recommendations for improvement of program in the faculty of education. Unpublished doctoral dissertation, Columbia University.

Krustchinsky, R., \& Moore, B. D. (1981). Early field experience: A vital part the training of elementary teachers. Kappa Delta Pi Record, 17.

Massialas, B. (1989). The inevitability of issue-centered discourse in the classroom. The Social Studies, 80(5), 173-175.

May 3rd 2005, from http://www.saudinf.com/main/e5.htm

Medley, D. \& Coker, H. (1987). How valid are principals' judgments of teacher effectiveness? Phi Delta Kappan, 69, (pp. 138-40).

Merrill. C. (1967). Professional student teaching program. Denville, Illinois: The Interstate Printer and Publisher, Inc.

Ministry of Education. (2000). Teachers' Colleges Agency. Riyadh, Saudi Arabia.

Ministry of Education. (1974). Education Policy in the Saudi Arabian Kingdom. Riyadh, Saudi Arabia.

Ministry of Education. (2001). A report on the progress of education in the Kingdom of Saudi Arabia. Riyadh, Saudi Arabia: Ministry of Education.

Ministry of Planning. (2000). Seventh development plan. Riyadh, Saudi Arabia: Ministry of Planning. Ministry of Planning. (1980). Third development plan for 1980-1985, S.A. Saudi Arabia: Ministry of Planning.

Mursi, M. M. (1981). The reference in comparative education. Cairo: Alam Al-Kutab. 
National Council for the Social Studies. (1982). Position statement on global education. Social Education, 46(1), 36-38.

National Council for the Social Studies. (1982). Position statement on global education. Social Education, 46 (1), pp. 376-387.

Nichols, J. O. (1995). A practitioner's handbook for institutional effectiveness and student outcomes assessment implementation (3rd Ed). New York: Agathon Press.

Nicklas, W. L. (1976). A follow-up study of the 1974-1975 graduates of North Texas State University who obtained certification to teach. (Doctoral dissertation, North Texas State University 1976). Dissertation Abstracts International, 37, 3564A.

Nunnally, J. (1978). Psychometric Theory. New York: McGraw-Hill.

O' Connor, P. (1988). The special responsibilities of educational institutions in America and Italy: To improve the social and civic values and behavior of their youth. Paper presented at the International Conference for the Development of Civic Responsibilities Among Youth, Urbino, Italy. (ERIC Document Reproduction Service No. ED 314 290).

Ochoa, A. (1988). Issues in teacher education reform: Implications for the preparation of social studies teachers. The Social Studies, 79(3), 121-123.

Pahl, R. (1990). Review of teaching for and learning social studies outcomes. The Social Studies,81(6),271-277.

Peter Airasian, L. R. Gay (2003). Educational research, Seventh Edition, published by Merrill Prentice, New Jersey.

Razik, T. (1992). Arab Gulf States. In Leavitt, H. B. Issues and problems in teacher education. New York: Greenwood Press.

Rhodes, G. S., \& Smith, V. A. (1975). In-service needs assessment social studies teachers in Indiana: Indiana council for the social studies, Inc. (ERIC Document Reproduction Service No. ED 125 967)

Rutman, L. (1980). Planning useful evaluation: Evaluability assessment. Beverly Hills: Sage Publications. Salant, P., \& Diliman, D. (1994). How to conduct your own survey. The United States of America: John Wiley \& Sons, Inc. 
Saudi Press Agency. (2003, December 4th). Population of the Kingdom: 23.3million. Al-watan daily newspaper.

Shadly, R. A. (1978). A study of the teacher training program at Riyadh University by survey of opinions of teacher education graduates with in-service experiences. Dissertation Abstracts International, 39, 2201A-2202A. (University Microfilms No. 78-19,028). Snyder, H. R. (1963). Community colleges education for Saudi Arabia Unpublished doctoral dissertation, Columbia University.

Snyder, H. R. (1963). Community college education for Saudi Arabia. Unpublished doctoral dissertation, Colombia University.

Stedman, D. J. (1980). Improving teacher education: Academic program review. Atlanta, Georgia: Southern Regional Education Board (ERIC Documents Reproduction Service No. ED 205 467).

Stratemeyer, F. B., \& Lindsey, M. (1958). Working with student teachers. New York: Bureau of Publications, Teachers College, Columbia University.

Tabouk Teachers' College Bulletin. (2005). Tabouk Teachers' College. Tabouk City, Saudi Arabia. Wesley, E . (1942). Teaching the social studies. Boston: D. C. Heath and Company.

Wolf, R. M. (1984). Evaluation in education: Foundation of competency assessment and program review. New York: Praeger Publishers. 
Appendix A

Letter of Participation

Dear/Student,

I am a doctoral student in the Educational Theory and Practice Department at West Virginia University. As part of my doctoral program, I am conducting a study on the perception of students toward the Social Studies Teacher Training Program at Tabouk Teachers' College in Saudi Arabia.

You are invited to participate in this survey because you are one of the few individuals who have knowledge about this particular topic. I recognize that there are many demands on your time. It is my hope that this research will provide useful and meaningful results that can be helpful in meeting today's challenges of social studies teacher training. I would greatly appreciate it if you would take just a few minutes of your time to complete the questionnaire. Please follow the instructions, but make sure that you do not write your name anywhere on the survey.

I would like to let you know that your participation in this survey is completely voluntary, and you don't have to respond to every item. Your academic status will not be affected if you choose not to participate. The information that I collect during the study will only be used to fulfill the dissertation requirements, and all responses provided on this survey will remain confidential.

If you have any questions or concerns about this questionnaire or the study, please do not hesitate to contact me by phone (304-692-5666), or through my e-mail address at Awad35@hotmail.com

alsheekhhassan@yahoo.com awad.abuhassan@gmail.com 
Thank you very much in advance for taking the time to answer the questions in the survey.

Sincerely,

Awad Alhwiti 
Appendix B

Survey Instrument

Part 1: Please circle the letter that most appropriately describes you.

Demographics

\begin{tabular}{|c|c|c|}
\hline \multirow[t]{3}{*}{1.} & \multirow[t]{3}{*}{ I have the following academic qualifications: } & a. Teacher Certificate \\
\hline & & b. Bachelor's degree \\
\hline & & c. Associate degree \\
\hline \multirow[t]{5}{*}{2.} & \multirow[t]{5}{*}{ How old are you? } & a. $20-29$ \\
\hline & & b. $30-39$ \\
\hline & & c. $40-49$ \\
\hline & & d. $50-59$ \\
\hline & & e. $60+$ \\
\hline \multirow[t]{5}{*}{3.} & \multirow[t]{5}{*}{ How many years have you been teaching? } & a. $1-4$ \\
\hline & & b. $5-9$ \\
\hline & & c. $10-14$ \\
\hline & & d. $15-19$ \\
\hline & & e. $20+$ \\
\hline \multirow[t]{4}{*}{4.} & \multirow[t]{4}{*}{ What was your GPA on graduation? } & a. $\quad$ less than 2.0 \\
\hline & & b. $2.0-2.9$ \\
\hline & & $3.0-3.9$ \\
\hline & & $\begin{array}{ll}\text { d. } & 4.0 \\
\end{array}$ \\
\hline \multirow[t]{5}{*}{5.} & \multirow[t]{5}{*}{ My home is/was ...... kilometers away from the teaching college } & a. $1-5$ \\
\hline & & b. $6-10$ \\
\hline & & c. $11-15$ \\
\hline & & d. $16-20$ \\
\hline & & e. more than 30 \\
\hline
\end{tabular}


Teacher Preparation Effectiveness 81
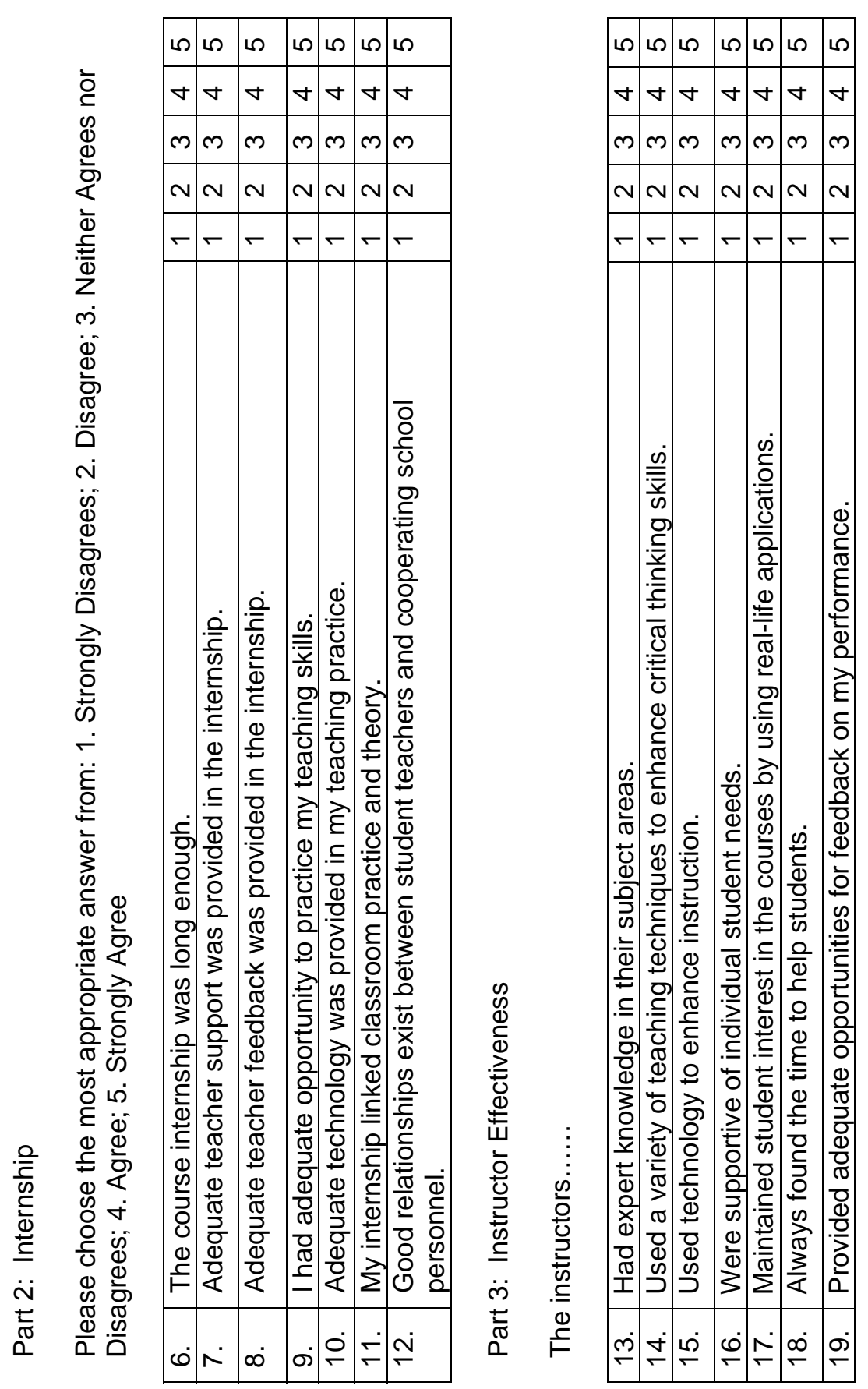
Teacher Preparation Effectiveness 82
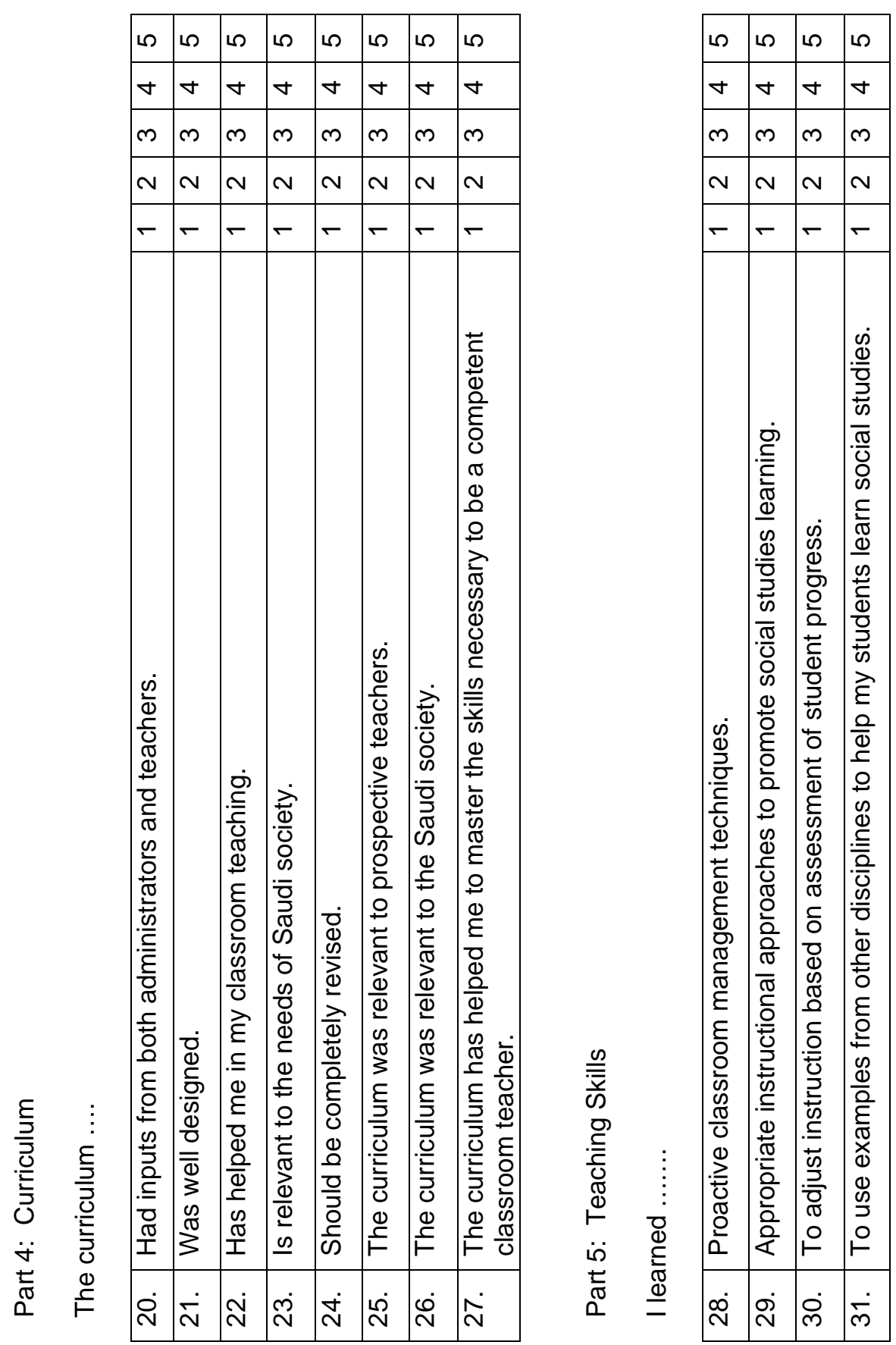
Teacher Preparation Effectiveness 83

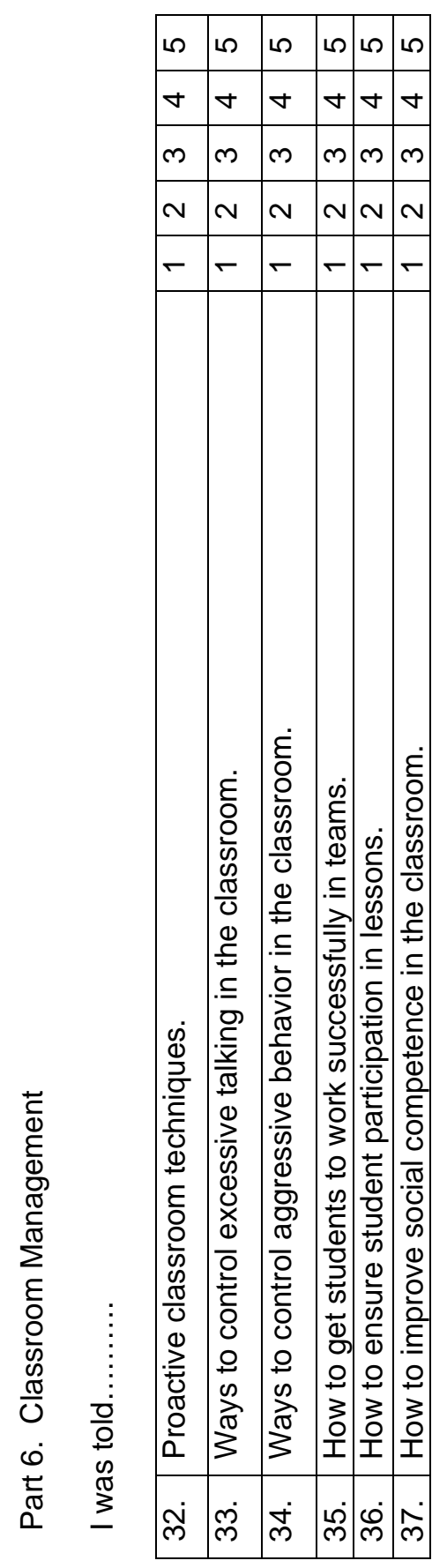




\section{CURRICULUM VITAE}

Awad Hamad Alhwiti attended Tabouk Teachers' College in Saudi Arabia where he earned the Bachelor's degree in Elementary Education. Awad also attended West Virginia University where he earned the Master of Arts in Elementary Education.

For several years, Awad served as an elementary school teacher in the Tabouk Region of Saudi Arabia. He is currently a faculty member at Tabouk Teacher's College where he works with those preparing to become elementary school teachers. 